\title{
Viruses in Extreme Environments, Current Overview, and Biotechnological Potential
}

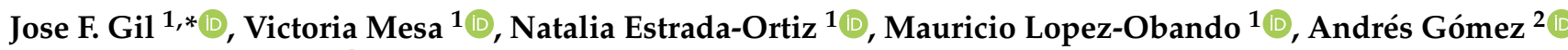 \\ and Jersson Plácido ${ }^{3, *(D)}$ \\ 1 VEDAS Corporación de Investigación e Innovación (VEDAS CII), Medellín 050024, Colombia; \\ victoria.mesa@vedascii.org (V.M.); natalia.estrada@vedascii.org (N.E.-O.); \\ mauricio.obando@vedascii.org (M.L.-O.) \\ 2 Department of Animal Science, Food Science and Nutrition, University of Minnesota, \\ St. Paul, MN 55108-6118, USA; gomeza@umn.edu \\ 3 Institute of Life Science, Medical School, Swansea University, Swansea SA2 8PP, UK \\ * Correspondence: jose.gil@vedascii.org (J.F.G.); jersson.placido@vedascii.org (J.P.)
}

check for

updates

Citation: Gil, J.F.; Mesa, V.;

Estrada-Ortiz, N.; Lopez-Obando, M.;

Gómez, A.; Plácido, J. Viruses in

Extreme Environments, Current Overview, and Biotechnological Potential. Viruses 2021, 13, 81. https://doi.org/10.3390/v13010081

Academic Editor: Eric O. Freed Received: 25 October 2020 Accepted: 29 December 2020 Published: 8 January 2021

Publisher's Note: MDPI stays neutral with regard to jurisdictional clai$\mathrm{ms}$ in published maps and institutional affiliations.

Copyright: (C) 2021 by the authors. Licensee MDPI, Basel, Switzerland. This article is an open access article distributed under the terms and conditions of the Creative Commons Attribution (CC BY) license (https:// creativecommons.org/licenses/by/ $4.0 /)$.

\begin{abstract}
Virus research has advanced significantly since the discovery of the tobacco mosaic virus (TMV), the characterization of its infection mechanisms and the factors that determine their pathogenicity. However, most viral research has focused on pathogenic viruses to humans, animals and plants, which represent only a small fraction in the virosphere. As a result, the role of most viral genes, and the mechanisms of coevolution between mutualistic viruses, their host and their environment, beyond pathogenicity, remain poorly understood. This review focuses on general aspects of viruses that interact with extremophile organisms, characteristics and examples of mechanisms of adaptation. Finally, this review provides an overview on how knowledge of extremophile viruses sheds light on the application of new tools of relevant use in modern molecular biology, discussing their value in a biotechnological context.
\end{abstract}

Keywords: extremophile viruses; virosphere; eukaryotic viruses; archaeal viruses; bacterial viruses

\section{Introduction}

Extremophile organisms are found in hostile environments; places where life was thought not to be possible. Facultative-adapted organisms, known as extremotolerant, can be found from toxic waste, acid and alkaline lakes, to high pressure, ice or extremely hot environments. Hence, organisms that require these extreme environments to survive are classified (or known) as extremophilic [1].

Depending on the environment that these organisms are isolated from, they can be classified as thermophiles (and hyperthermophiles: from very high temperatures), psychrophiles (from low temperatures), acidophiles and alkaliphiles (from acid or alkaline environments), barophiles (from high pressure environments) and halophiles (from saline environments) [1,2] (See [2] for details). Extremophiles, either extremotolerant or extremophilic, are highly diverse, including species in the three domains of life: bacteria, archaea and eukaryote. Recently, it has been possible to extend their sampling coverage; partially due to climate change, which has made possible to find extremophiles in places where it was not possible to reach out before. Moreover, due to advances in sampling and sequencing technologies (e.g., high-throughput sequencing), it has been possible to access more information on the taxonomy and function of these organisms [3].

The discovery of virus infecting these organisms resulted from investigating microbial communities in extreme environments, indicating that all living organisms on earth are hosts of viruses and that viruses are the most abundant biological entities on the planet [4] Moreover, it has been established that extremophiles act as hosts for viral replication and that viruses are responsible for the balance of population dynamics in extreme environments [5]. In this regard, several studies have analyzed prokaryotic (Bacteria and Archaea) 
and Eukaryotic abundance and diversity along different extreme environments [6-8]. In contrast, little is known about their viral co-symbionts and their ecological roles across niches within harsh life conditions around the world [9]. Furthermore, numerous ecological studies have revealed that prokaryotic viruses predominate across different environments, including extreme niches, and outnumbering their hosts by at least an order of magnitude [10,11]. Thus, documenting viral diversity in extremophile hosts, from molecular and taxonomic perspectives, provides vital information about how viruses shaped life on earth and about the viral molecular mechanisms involved in this process, which could constitute a source of novel molecular tools for biotechnological applications. This review focuses on what is known about viruses infecting extremophile organisms, and brings particular examples on how research on extremophile viruses sheds light on their potential use as sources for biotechnological tools.

\section{Viruses of Extremophile Archaea}

Archaea are organisms that share several biological characteristics with both bacteria and eukaryotes, and such similarities vary depending on taxonomic classification (Reviewed in [12]). Archaea were considered only to thrive in extreme environments; however, they have been found in several mesophilic ecosystems, where they flourish thanks to the acquisition of adaptive genes from bacteria [13-16]. One of the most interesting findings was the identification of archaea on the human body. Among them, methanogens found in the colon represent an important community with potentially defining roles in digestive function, along with those colonizing the subgingival plaque, and skin [17]. To add-on their captivating lifestyles, research on extremophilic archaea is receiving increasing attention due to the viruses that have been found associated with their populations. These observations suggest that viruses infecting archaea might represent the most diverse and abundant biological entities on earth [18].

Viruses infecting archaea have an important role in influencing global biogeochemical cycles; they are responsible for the production of approximately 0.3 to 0.5 gigatonnes of carbon per year, only by lysis of archaeal cells in the top $50 \mathrm{~cm}$ in the surface deep-sea sediments [19]. Despite this important role, little is known about their genomic characteristics. Globally, $75-90 \%$ of genes in archaeal viruses (depending on the taxa) lack significant sequence match or homology in public databases, making their functional annotation difficult and limiting knowledge on their biology and specific functions in extreme niches [12,20]. Table 1 summarizes relevant examples of viruses isolated from extremophile archaea and their main taxonomic features $[12,21,22]$. 
Table 1. Main features of the archaeal viruses characterized in extreme environments.

\begin{tabular}{|c|c|c|c|c|c|c|c|}
\hline $\begin{array}{c}\text { Environment Parameter/ } \\
\text { Habitat }\end{array}$ & Virus (Host) & Family & Capsid Morphology & Additional Features & Genome Type & Isolation Origin & Reference \\
\hline $\begin{array}{l}\text { Temperature } \\
>50^{\circ} \mathrm{C} \\
\text { Hot spring }\end{array}$ & $\begin{array}{c}\text { PFV1 virion (archaeal genus } \\
\text { Pyrobaculum) }\end{array}$ & Tristromaviridae & $\begin{array}{l}\text { Rod-shaped helical } \\
\text { nucleocapsid and a } \\
\text { nucleocapsid- } \\
\text { encompassing protein } \\
\text { sheath }\end{array}$ & $\begin{array}{l}\text { Contains an envelope and } \\
\text { an inner core }\end{array}$ & dsDNA & $\begin{array}{c}\text { Hyperthermophilic } \\
\text { archaea. Pozzuoli Solfatara, } \\
\text { Italy }\end{array}$ & [23] \\
\hline Hot acidic spring & $\begin{array}{l}\text { SSV1 (Sulfolobus solfataricus } \\
\text { PH1) }\end{array}$ & Fuselloviridae & Icosahedral & six-fold symmetric tail & dsDNA & $\begin{array}{l}\text { Hyperthermophilic } \\
\text { archaea }\end{array}$ & [24] \\
\hline Hot acidic spring & $\begin{array}{l}\text { ATV (Sulfolobus, Acidianus, } \\
\text { Thermoproteus, Pyrobaculum) }\end{array}$ & $\begin{array}{l}\text { Fuselloviridae, Lipothrixviridae, } \\
\text { Rudiviridae, Guttaviridae, } \\
\text { Globuloviridae, Ampullaviridae }\end{array}$ & Icosahedral & six-fold symmetric tail & dsDNA & $\begin{array}{l}\text { Hyperthermophilic } \\
\text { archaea }\end{array}$ & [25] \\
\hline Hot springs & Metagenomic search & $\begin{array}{c}\text { Ampullaviridae, Bicaudaviridae, } \\
\text { Lipothrixviridae and } \\
\text { Rudiviridae }\end{array}$ & & & dsDNA & $\begin{array}{l}\text { Metagenomes isolated } \\
\text { worldwide }\end{array}$ & [26] \\
\hline Hot springs & $\begin{array}{c}\text { Metallosphaera turreted } \\
\text { icosahedral virus (MTIV) } \\
\text { (Metallosphaera yellowstonensis, } \\
\text { MK1) }\end{array}$ & & Icosahedral & $\begin{array}{l}\text { Unusual structure that has } \\
42 \text { turret-like projections: } \\
12 \text { from each of the } 5 \text {-fold } \\
\text { axes and } 30 \text { hexameric } \\
\text { units positioned on } \\
\text { icosahedral 2-fold axes }\end{array}$ & dsDNA & $\begin{array}{l}\text { Hot springs water samples } \\
\text { collected from Yellowstone } \\
\text { National Park }\end{array}$ & [27] \\
\hline Hot springs & $\begin{array}{l}\text { Thermus virus P23-77 } \\
\text { (Thermus thermophilus) }\end{array}$ & Tectiviridae & Icosahedral & & dsDNA & $\begin{array}{c}\text { Alkaline hot spring New } \\
\text { Zealand }\end{array}$ & [28] \\
\hline Hot springs & $\begin{array}{c}\text { SBFV1, SBFV2, SBFV3, SBRV1, } \\
\text { SPV1, SPV2, SBV1 } \\
\text { (Sulfolobales) }\end{array}$ & $\begin{array}{c}\text { Portogloboviridae, Rudiviridae, } \\
\text { Lipothrixviridae }\end{array}$ & Icosahedral & $\begin{array}{l}\text { Filamentous and } \\
\text { rod-shaped viruses }\end{array}$ & dsDNA & $\begin{array}{c}\text { Hot spring Umi Jigoku in } \\
\text { Beppu, Japan }\end{array}$ & {$[1]$} \\
\hline $\begin{array}{c}\text { Temperature } \\
81-96^{\circ} \mathrm{C} \text { and } \mathrm{pH} 1-7\end{array}$ & $\begin{array}{l}\text { MRV1, ARV3, SSRV1, PSV2, } \\
\text { PFV2 (Pyrobaculum, } \\
\text { Saccharolobus, Acidianus, } \\
\text { Metallosphaera) }\end{array}$ & $\begin{array}{l}\text { Rudiviridae, Globuloviridae } \\
\text { and Tristromaviridae }\end{array}$ & & $\begin{array}{l}\text { Rod-shaped and spherical } \\
\text { viruses }\end{array}$ & dsDNA & $\begin{array}{c}\text { Hyperthermophilic } \\
\text { archaea. Pozzuoli Solfatara, } \\
\text { Italy }\end{array}$ & [2] \\
\hline $\begin{array}{l}\text { Temperature } \\
80^{\circ} \mathrm{C} \text { and } \mathrm{pH} 3 \\
\text { Saturated salts } \\
\text { salinity level } \\
(8-36 \%)\end{array}$ & SIRV2 (Sulfolobus islandicus) & Rudiviridae & $\begin{array}{l}\text { Non-enveloped, rod- } \\
\text { shaped virus }\end{array}$ & $\begin{array}{l}\text { Flexible filamentous } \\
\text { particle } 830 \mathrm{~nm} \text { long and } \\
8 \mathrm{~nm} \text { wide }\end{array}$ & dsDNA & $\begin{array}{l}\text { Hyperthermophilic } \\
\text { acidophilic archaeon } \\
\text { Sulfolobus islandicus }\end{array}$ & [29] \\
\hline
\end{tabular}


Table 1. Cont.

\begin{tabular}{|c|c|c|c|c|c|c|c|}
\hline $\begin{array}{c}\text { Environment Parameter/ } \\
\text { Habitat }\end{array}$ & Virus (Host) & Family & Capsid Morphology & Additional Features & Genome Type & Isolation Origin & Reference \\
\hline $\begin{array}{c}\text { Temperature } \\
80^{\circ} \mathrm{C} \text { and } \mathrm{pH} 3 \\
\text { Saturated salts } \\
\text { salinity level } \\
(8-36 \%)\end{array}$ & $\begin{array}{c}\text { HRPV, SCTP, HRTV, HHTV, } \\
\text { HCTV, HHPV, HSTV, HHIV, } \\
\text { HJTVHVTV, HGTV, HATV, } \\
\text { SSIP, HGPV (Halorubrum, } \\
\text { Haloarcula, Halogeometricum, } \\
\text { Halogranum, Salicola, Salisaeta) }\end{array}$ & & & & ssDNA & $\begin{array}{l}\text { Hypersaline water and salt } \\
\text { crystal samples collected } \\
\text { from Italy, Thailand, Israel; } \\
\text { Slovenia and Spain }\end{array}$ & [30] \\
\hline Hypersaline environments & $\begin{array}{c}\text { Haloarcula californiae } \\
\text { icosahedral virus } 1 \text { (HCIV-1) }\end{array}$ & Sphaerolipoviridae & Icosahedral & $\begin{array}{l}\text { Tailed and two non-tailed } \\
\text { virus morphotypes }\end{array}$ & dsDNA & Solar saltern, Thailand & [31] \\
\hline
\end{tabular}


Archaeal viruses classified so far are grouped within DNA viruses, both having dsDNA and ssDNA genomes. Viruses within the dsDNA group have been divided in 13 families: Ampullaviridae (bottle-shaped), Bicaudaviridae (spindle-shaped), Clavaviridae (club, stick), Fuselloviridae (spindle-shaped), Guttaviridae (droplet-shaped), Globuloviridae (round-shaped), Lipothrixviridae (fat hair-shaped), Myoviridae (muscle, referring to the contractile tail), Portogloboviridae (carrying ball), Rudiviridae (small rod), Sphaerolipoviridae (fat sphere), Tristromaviridae (three layer) and Turriviridae (turret-like appendages expanding from the capsid); while ssDNA group contains only two families Pleolipoviridae (many lipid) and Spiraviridae (coil-shaped) [12,32]. Myoviridae is the only family, to date, that infects both bacteria and archaea [32].

The biggest challenge faced when attempting to characterize archaeal viruses is the difficulty with isolation and culturing their hosts. Due to the high diversity of virion morphotypes and genome content of archaeal viruses, it is believed that we are just starting to grasp the real diversity of this group of viruses. This diversity has derived in the creation of taxonomic families that better explain and fit archaeal viruses' characteristics [33].

A better understanding of the interactions between archaea and their viruses, and the impact of viral co-symbionts on community ecology requires studying the environments they inhabit, along with the detailed taxonomy, morphology and functional genomics of the isolated viruses. This also includes the study of viral mechanisms involved in host adaptation to extreme environments, [21,34-36]. For example, in hyperthermophilic environments, viruses classified within the family Fuselloviridae infect the thermoacidophilic genus Sulfolobus [37,38]. Organisms within this genus have been used as a model to understand archaeal interactions with their viruses, including immune system responses [38]. Sulfolobus spindle-shaped virus 1 (SSV1) (dsDNA) is highly tolerant to mutations, being able to evade insertions and deletions in $\sim 50 \%$ of its coding sequence, which is the same proportion of genes that are not essential for infectivity [39]. These non-essential ORFs (coding for $<100$ aa putative proteins) might be non-coding RNAs [39], which can act as regulatory molecules in the host [40]. Possibly, these genes, which are susceptible to modifications but that have no impact on the integrity of the virus and its infectivity, are or were required for adaptation to compete with other viruses or environmental conditions [39]. So far, these remain as hypotheses to be tested. In contrast, other members of the Fuselloviridae family, such as SSV10, encode a putative CRISPR associated Cas4-like ORF [38]. This protein is predicted to show high reliability and matches with several Cas4 and RecB ( $3^{\prime}$ to $5^{\prime}$ helicase, nuclease) protein structures found in several bacteria and archaea, as well as conserved motifs and active sites, among which $5^{\prime}$ to $3^{\prime}$ exonuclease activity is highlighted [38]. It is speculated that the protein produced from this ORF may have a counter activity against archaeal immune responses or, a multifunctional response against different stress responses (discussed in [38]).

Other mechanisms that mediate adaptation to extreme environments have been described such as a form of virion organization. For example, packing A-form DNA and disulfides in intracellular viral proteins. In the first one, almost half of the capsid protein is unstructured in solution, this unstructured region folds in the virion into a single extended $\alpha$-helix which wraps around the DNA. The DNA is entirely in A-form, suggesting a mechanism for protecting DNA in the most adverse environments. The finding that the genomic dsDNA within the icosahedral capsid adopts an A-form has been reported in viruses as Sulfolobus polyhedral virus 1 (SPV1) and Sulfolobus SIRV2 [29,41]. In the second mechanism mentioned, intracellular disulfide bonds are present. These bonds are common in cellular proteins of Sulfolobus turreted icosahedral virus (STIV), in which a 93-residue protein has been reported and its characterization reveals a homodimeric winged-helix protein that is likely to function as a transcriptional regulator, suggesting the enhancing of the thermostability of the viral proteome [42]. 


\section{Viruses of Extremophile Bacteria}

Bacterial viruses (also known as bacteriophages or phages) are estimated to be the most abundant and diverse biological entities on the planet [43]; therefore, detectable in almost every biological niche, representing a vast source of biodiversity [44,45]. They can influence the abundance, diversity and evolution of bacterial communities; for instance, by supporting ecosystem homeostasis, as reported in marine ecosystems [43]. In these environments, viruses control prokaryotic and phytoplankton mortality, influencing microbial diversity and niche metabolic turnover [46]. For example, in geothermal environments, thermophilic phages also play significant roles in biogeochemistry, ecology and genetic exchange $[47,48]$. These roles are also common in archaeal communities, which highlights the importance of viruses for global ecology dynamics.

Bacteriophages are found as DNA or RNA with single- and double-stranded genomes [32]. The reported bacterial virus dsDNA families belong to the order Caudovirales (dsDNA) as Myoviridae, Siphoviridae and Podoviridae. In addition, viruses in the families Tectiviridae, Corticoviridae, Plasmaviridae and Sphaerolipoviridae have dsDNA genomes, but are not grouped within a taxonomical order. ssDNA viruses include families Microviridae and Inoviridae. Families Cystoviridae and Picobirnaviridae are grouped within dsRNA viruses, while family Leviviridae in ssRNA viruses [32]. Altogether viruses classified within these taxonomic families infect more than 140 bacterial genera and their classification depends greatly on their morphotypes and host genera. About $96 \%$ of phages are tailed, from which $61 \%$ correspond to Siphoviridae. The other types of phages $(3.6 \%)$ are cubic, filamentous, or pleomorphic [10,45,49].

Geobacillus kaustophilus, Bacillus stearothermophilus and Thermus strains commonly harbor viruses within the families Siphoviridae and Myoviridae in thermophilic environments [48,50-52]. To date, little is known about bacterial population inhabiting hypersaline environments distributed globally in the form of salt lakes and salt ponds, and even less is known about their viral co-symbionts [53]. Ten viruses have been identified infecting halobacteria, particularly Deleya halophile, Halomonas halophile, Pseudomonas sp., Salinivibrio costicolan sp., Salicola sp., Salisaeta sp., Salinivibrio sp. In the case of cryophilic environments, the prevailing viral families are Myoviridae and Siphoviridae, infecting bacteria within the genera Shewanella, Flavobacterium and Colwellia. On the other hand, in acidic systems, the species Acidithiobacillus caldus has been associated with viruses from the Myoviridae family [54]. Additional relevant examples of viruses infecting bacteria are listed in Table 2. 
Table 2. Main features of the bacterial viruses characterized in extreme environments.

\begin{tabular}{|c|c|c|c|c|c|c|c|c|}
\hline $\begin{array}{c}\text { Environment } \\
\text { Parameter/ } \\
\text { Habitat }\end{array}$ & Virus (Host) & Family & $\begin{array}{c}\text { Capsid } \\
\text { Morphology }\end{array}$ & Additional Features & $\begin{array}{l}\text { Genome } \\
\text { Type }^{b}\end{array}$ & Isolation Origin & Host Features & Reference \\
\hline $\begin{array}{l}\text { Temperature } \\
\quad>50{ }^{\circ} \mathrm{C} \\
\text { Compost pile }\end{array}$ & $\begin{array}{c}\text { GBK2 (Geobacillus } \\
\text { kaustophilus) }\end{array}$ & Siphoviridae & Icosahedral & $\begin{array}{c}\text { Tail (long } \\
\text { non-contractile) }\end{array}$ & dsDNA & $\begin{array}{c}\text { Thermophilic } \\
\text { bacteria. Cary, NC, } \\
\text { USA }\end{array}$ & $\begin{array}{l}\text { Geobacillus species are } \\
\text { Gram-positive } \\
\text { thermophilic bacteria } \\
\text { that can ferment C-5 } \\
\text { and C- } 6 \text { sugars to mixed } \\
\text { acids and ethanol and } \\
\text { have potential for } \\
\text { biofuel production }\end{array}$ & [51] \\
\hline $\begin{array}{c}\text { Temperature } \\
70-90{ }^{\circ} \mathrm{C} \\
\text { Hot spring } \\
\text { sediment }\end{array}$ & $\begin{array}{c}\phi \mathrm{OH} 3 \\
\text { (Thermus thermophiles) }\end{array}$ & Inoviridae & Filamentous & $\begin{array}{l}\text { flexible filamentous } \\
\text { particle } 830 \mathrm{~nm} \text { long } \\
\text { and } 8 \mathrm{~nm} \text { wide }\end{array}$ & ssDNA & $\begin{array}{l}\text { Hyperthermophilic } \\
\text { bacterium Thermus } \\
\text { thermophilus HB8, } \\
\text { Obama hot spring, } \\
\text { Nagasaki, Japan }\end{array}$ & $\begin{array}{l}\text { Thermusbacteria, with } \\
\text { optimal growth } \\
\text { temperatures of } \\
70-75^{\circ} \mathrm{C} \text {, are found in } \\
\text { alkaline hot springs, hot } \\
\text { water heaters and } \\
\text { natural waters subjected } \\
\text { to thermal pollution }\end{array}$ & [48] \\
\hline $\begin{array}{l}\text { Temperature } \\
\text { High: } \\
70^{\circ} \mathrm{C} \\
\text { Alkaline hot } \\
\text { springs }\end{array}$ & $\begin{array}{l}115 \text { thermophilic phage } \\
\text { strains on seven } \\
\text { Thermus strains } \\
\text { (T. aquaticus ATCC } 25104, \\
25105 \text { and } 31558, \text { T. filiformis } \\
\text { ATCC } 43280, \text { T. flavus ATCC } \\
\text { 33923, T. lacteus ATCC } \\
\text { 31557, T. rubens ATCC } \\
\text { 31556, T. ruber ATCC } 35948, \\
\text { T. thermophiles ATCC 27634, } \\
\text { Thermus spp. ATCC 27737, } \\
\text { 27978 and 31674) }\end{array}$ & $\begin{array}{l}\text { Myoviridae, } \\
\text { Siphoviridae, } \\
\text { Tectiviridae and } \\
\text { Inoviridae }\end{array}$ & Icosahedral & $\begin{array}{l}\text { Myoviridae (phages } \\
\text { with contractile tails), } \\
\text { Siphoviridae (phages } \\
\text { with long and } \\
\text { noncontractile tails), } \\
\text { Tectiviridae (isometric } \\
\text { capsids) Inoviridae } \\
\text { (filamentous) }\end{array}$ & $\begin{array}{l}\text { dsDNA, } \\
\text { ssDNA }\end{array}$ & $\begin{array}{l}\text { Hyperthermophilic } \\
\text { Thermus species. } \\
\text { Alkaline hot } \\
\text { springs in Iceland, } \\
\text { New Zealand, } \\
\text { Russia } \\
\text { (Kamchatka), and } \\
\text { the U.S.A. }\end{array}$ & $\begin{array}{l}\text { Thermusbacteria, with } \\
\text { optimal growth } \\
\text { temperatures of } \\
70-75^{\circ} \mathrm{C} \text {, are found in } \\
\text { alkaline hot springs, hot } \\
\text { water heaters and } \\
\text { natural waters subjected } \\
\text { to thermal pollution }\end{array}$ & {$[52]$} \\
\hline
\end{tabular}


Table 2. Cont

\begin{tabular}{|c|c|c|c|c|c|c|c|c|}
\hline $\begin{array}{l}\text { Environment } \\
\text { Parameter/ } \\
\text { Habitat }\end{array}$ & Virus (Host) & Family & $\begin{array}{c}\text { Capsid } \\
\text { Morphology }\end{array}$ & Additional Features & $\begin{array}{l}\text { Genome } \\
\text { Type }^{b}\end{array}$ & Isolation Origin & Host Features & Reference \\
\hline \multirow{2}{*}{$\begin{array}{l}\text { Temperature } \\
\text { Deep-sea } \\
\text { hydrothermal } \\
\text { fields }\end{array}$} & $\begin{array}{l}\text { Bacillus virus W1, BVW1 } \\
\quad \text { (Bacillus sp. w13) }\end{array}$ & Siphoviridae & Icosahedral & $\begin{array}{l}\text { Long tail }(300 \mathrm{~nm} \text { in } \\
\text { length and } 15 \mathrm{~nm} \text { in } \\
\text { width) and a } \\
\text { hexagonal head } \\
\text { (70 nm in diameter) }\end{array}$ & dsDNA & \multirow{2}{*}{$\begin{array}{l}\text { Thermophilic } \\
\text { bacteria. } \\
\text { east-Pacific and } \\
\text { west-Pacific } \\
\text { hydrothermal } \\
\text { fields }\end{array}$} & & \multirow{2}{*}[50]{} \\
\hline & $\begin{array}{l}\text { Geobacillus virus E1, GVE1 } \\
\text { (Geobacillus sp. E26323) }\end{array}$ & Siphoviridae & Icosahedral & $\begin{array}{c}\text { Hexagonal head } \\
\text { (130 nm in diameter) } \\
\text { and a tail (180 nm in } \\
\text { length and } 30 \mathrm{~nm} \text { in } \\
\text { width) }\end{array}$ & dsDNA & & & \\
\hline $\begin{array}{l}\text { Temperature } \\
\quad 0^{\circ} \mathrm{C} \\
\text { Artic sea ice }\end{array}$ & $\begin{array}{c}\text { 1a (Shewanella frigidimarina), } \\
\text { 11b (Flavobacterium } \\
\text { hibernum), 21c (Colwellia } \\
\text { psychrerythraea) }\end{array}$ & Myoviridae/Siphoviridae & Icosahedral & Tailed & dsDNA & $\begin{array}{c}\text { Marine } \\
\text { psychrophilic } \\
\text { phage-host } \\
\text { systems from } \\
\text { Svalbard (Arctic) }\end{array}$ & & [55] \\
\hline
\end{tabular}


Table 2. Cont.

\begin{tabular}{|c|c|c|c|c|c|c|c|c|}
\hline $\begin{array}{l}\text { Environment } \\
\text { Parameter/ } \\
\text { Habitat }\end{array}$ & Virus (Host) & Family & $\begin{array}{c}\text { Capsid } \\
\text { Morphology }\end{array}$ & Additional Features & $\begin{array}{l}\text { Genome } \\
\text { Type }^{b}\end{array}$ & Isolation Origin & Host Features & Reference \\
\hline $\begin{array}{c}\mathrm{pH} \\
\text { Low: } 0-2{ }^{\circ} \mathrm{C} \\
\text { Acid mine } \\
\text { drainage }\end{array}$ & $\begin{array}{c}\text { AcaML1 } \\
\text { (Acidithiobacillus caldus } \\
\text { ATCC 51756) }\end{array}$ & Myoviridae & Icosahedral & Tail (contractile) & dsDNA & $\begin{array}{c}\text { Acidophile } \\
\text { bacteria, Chile }\end{array}$ & $\begin{array}{c}\text { Acidithiobacillus are } \\
\text { gammaproteobacteria } \\
\text { that are ubiquitous in } \\
\text { biomining biotopes, } \\
\text { with several } \\
\text { characterised species } \\
\text { that play key roles in } \\
\text { industrial metal } \\
\text { recovery }\end{array}$ & [54] \\
\hline $\begin{array}{c}\text { Saturated salts } \\
7.5 \% \mathrm{NaCl} \\
\text { (wt/vol) } \\
\text { Hypersaline soils }\end{array}$ & $\begin{array}{c}\text { F9-11 } \\
\text { (Deleya halophile) }\end{array}$ & - & - & $\begin{array}{l}\text { Isometric head and } \\
\text { non-contractile tail }\end{array}$ & - & $\begin{array}{c}\text { Halophilic } \\
\text { bacteria } \\
\text { Alicante (Spain) }\end{array}$ & Deleya halophile F9-11 & [57] \\
\hline $\begin{array}{l}\text { Saturated salts } \\
\text { Hypersaline soils }\end{array}$ & $\begin{array}{c}\text { ФgspA, } \Phi g s p B, \Phi g s p C \\
\Phi g s p D \text { and } \Phi g s p E \\
\text { (Halomonas spp.) }\end{array}$ & Myoviridae & Icosahedral & Tailed & dsDNA & $\begin{array}{l}\text { Great Salt Plains } \\
\text { National Wildlife } \\
\text { Refuge (GSP). } \\
\text { North-central } \\
\text { Oklahoma, USA }\end{array}$ & Halomonas spp. & [58] \\
\hline $\begin{array}{l}\text { Saturated salts } \\
\text { 6\% } \mathrm{NaCl}(\mathrm{wt} / \mathrm{vol}) \\
\text { Soda lakes }\end{array}$ & $\begin{array}{c}\text { Mgbh1, Shbh1 } \\
\text { (Bacillus sp.) } \\
\text { Shpa (Paracoccus marinus) }\end{array}$ & $\begin{array}{l}\text { Myoviridae } \\
\text { Siphoviridae }\end{array}$ & Icosahedral & Tailed & dsDNA & $\begin{array}{l}\text { East African Rift } \\
\text { Valley soda lakes }\end{array}$ & $\begin{array}{l}\text { Bacillus sp./Paracoccus } \\
\text { marinus. Bacillus- and } \\
\text { Paracoccus species have } \\
\text { important roles in } \\
\text { biogeochemical cycling } \\
\text { in soda lakes }\end{array}$ & [59] \\
\hline $\begin{array}{l}\text { High hydrostatic } \\
\text { pressure } \\
(\sim 381 \mathrm{mbsf})^{\text {a }} \\
\text { Deep subsea floor }^{\text {sediments }}\end{array}$ & $\begin{array}{c}\text { RR1-A } \\
\text { RR1-B } \\
\text { (Rhizobium radiobacter) }\end{array}$ & - & - & - & - & $\begin{array}{l}\text { Peru margin area } \\
\text { to the open ocean } \\
\text { of the eastern } \\
\text { equatorial Pacific }\end{array}$ & $\begin{array}{l}\text { Rhizobium radiobacter is } \\
\text { the most frequently } \\
\text { isolated and highly } \\
\text { abundant representative } \\
\text { of the marine deep } \\
\text { subsurface }\end{array}$ & {$[60]$} \\
\hline
\end{tabular}

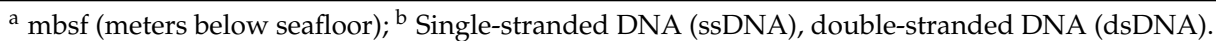


In psychrophilic phage-host interactions, bacteriophage 9A, which infects the marine psychrophilic gamma-proteobacterium Colwellia psychrerythraea strain $34 \mathrm{H}(\mathrm{Cp} 34 \mathrm{H})$ (temperatures between -12 and $8^{\circ} \mathrm{C}$ ), has been analyzed to investigate the potential role of 9A genes in host adaptations to cold temperatures. Colangelo-Lillis et al. [56] identified candidates for auxiliary metabolic genes (AMGs) involved in this adaptation, such as the homolog of a cold-active alkaline serine protease $(h p-122$, which is reported to enhance nutrient acquisition during phage replication), an extracellular enzyme of $C p 34 H$, and several genes related to phosphate metabolism (e.g., nicotinamide mononucleotide adenylyltransferase, nicotinamide phosphoribosyl transferase). Other 9A genes may also be involved in facilitating interactions between phage and host; such as the genes 9A homolog (hp-132) of Cp34H histone deacetylase and 9A homolog (hp-141) of Cp34H DNA topoisomerase III. The $h p-132$ gene is involved in high-affinity binding between histones and DNA and it might inhibit transcription of proteins involved in defense of the host. The $h p-141$ is believed to be involved in adaptation to cold stress [56].

\section{Viruses of Extremophile Eucaryotes}

The abundance and diversity of eukaryotic extremophiles is significantly lower compared to what has been observed in extremophile bacteria and archaea; therefore, the diversity of viruses in eukaryotic extremophiles has been less documented. Bacteria, archaea and eukaryotes show domain specific viromes and mobilomes, with archaea and bacteria sharing numerous dsDNA virus families [61]. However, Eukaryotes host a greater diversity of RNA viruses, reverse transcribing elements and retroviruses than archaea and bacteria [61]. As more advances in genomics and in metabolomics techniques uncover eukaryotic diversity and function in extreme conditions (reviewed in [62]), more information about their viral co-symbionts will be revealed.

Deep sea and polar conditions are the main extreme environments in which viral infections have been reported, primarily in extremophile animals $[63,64]$. These studies have helped to predict epidemiological risks of mesophilic viruses. An example of viruses infecting eukaryotic extremophiles is seen in artic (tundra-boreal) environments between non-hematophagous insects (Chaoborus spp.) and phasmaviruses (Bunyaviridae) in artic environments; in what seems to be a long-term coevolutionary relationship between virus and host [65]. For instance, the Kigluaik phantom virus (KIGV) infects polar phantom midges and has been transmitted vertically in Chaoborus trivittatus (North American populations) for thousands of years. The high prevalence of the virus in the insect population is evidence that this coevolutionary relationship leads to endosymbiosis [65]. Table 3 describes the characteristics of viruses found in extremophile animals. 
Table 3. Virus in extremophile animals.

\begin{tabular}{|c|c|c|c|c|c|c|c|}
\hline Virus Type & Known Host & Isolation Origin & $\begin{array}{l}\text { Geographic } \\
\text { Range }\end{array}$ & $\begin{array}{c}\text { Genes or Molecular Traits } \\
\text { Followed }\end{array}$ & $\begin{array}{l}\text { Genome Size and } \\
\text { Other Genetic Traits }\end{array}$ & Accession Numbers & References \\
\hline $\begin{array}{l}\text { Eukaryotic circular } \\
\text { Rep-ncoding ssDNA } \\
\text { (CRESS-DNA) viruses }\end{array}$ & Marine invertebrates & Deep sea & - & $\begin{array}{l}\text { Metagenomics analysis } \\
\text { Putative cap }\end{array}$ & $\begin{array}{c}\text { Eukaryotic circular } \\
\text { Rep-encoding } \\
\text { ssDNA } \\
\end{array}$ & $\begin{array}{l}\text { KR528543 to } \\
\text { KR528569 }\end{array}$ & {$[66]$} \\
\hline Eukaryotic virus SSDNA & - & $\begin{array}{l}\text { Deep sea } \\
\text { hadopelagic } \\
\text { sediments }\end{array}$ & $\begin{array}{l}\text { Pacific Ocean } \\
\text { japan }\end{array}$ & $\begin{array}{l}\text { Methagenomics analysis } \\
\text { genetic markers (major } \\
\text { capsid protein [VP1] and } \\
\text { replication protein [Rep]) }\end{array}$ & $\begin{array}{c}\text { Eukaryotic virus } \\
\text { ssDNA }\end{array}$ & $\begin{array}{c}\text { DRA000564 } \\
\text { BAKA01000001 to } \\
\text { BAKA01000006 } \\
\text { BAKB01000001 to } \\
\text { BAKB01000011 } \\
\text { BAKC01000001 to } \\
\text { BAKC01000114 }\end{array}$ & [67] \\
\hline $\begin{array}{c}\text { Phocine herpesvirus } 1 \\
\text { (PhHV-1) }\end{array}$ & $\begin{array}{c}\text { Harbor seals } \\
\text { (Phoca vitulina) }\end{array}$ & Polar & Norway & glycoprotein B gene & Large dsDNA & - & {$[68]$} \\
\hline $\begin{array}{c}\text { Kigluaik phantom virus } \\
\text { (KIGV) } \\
\text { Nome phantom virus } \\
\text { (NOMV) }\end{array}$ & $\begin{array}{l}\text { Phantom midges } \\
\text { (Chaoborus) }\end{array}$ & Polar & Arctic & $\begin{array}{l}\text { The endonuclease domain to } \\
\text { motif } E \text { of the conserved } \\
\text { polymerase domains }\end{array}$ & $3(-)$ ssRNA segments & $\begin{array}{l}\text { KJ434182 to KJ434187 } \\
\text { KJ461793 to KJ461811 }\end{array}$ & {$[65]$} \\
\hline
\end{tabular}


Regarding microorganisms, the greatest number of viruses of eukaryotes has been described in deep-sea phytoplankton [69] and polar environments [70]; nevertheless, geothermal locations (soil and lakes) are also a source of extremophile eukaryotic microorganisms and their viruses [71]. Table 4 details some of the characteristics associated with viruses found infecting extremophile eukaryotic microorganisms.

In polar environments and deep-sea, the principal source of viruses in eukaryotic microorganisms is associated with the viral shunt, an ecological mechanism that allows microbial recycling processes in the oceans [72]. Micromonas pusilla viruses $(\mathrm{MpV})$ have been studied under different conditions, such as temperature, carbon dioxide $\left(\mathrm{CO}_{2}\right)$, phosphorous limitation and iron limitation [73]. The $\mathrm{MpV}$ viral burst is affected by phosphorus and iron limiting conditions, these limited conditions prolong its latency period [73] and reduce its infectivity in about $70 \%$ [74]. In contrast, a steady low supply of soluble reactive phosphorus increases the viral burst [69].

With the advance of methodologies for massive parallel sequencing and metagenomics, it has become increasingly easier to study viromes of eukaryotic organisms in extreme environments [5]. This is the case of Emiliania huxleyi phytoplankton (coccolithophore), large dsDNA viruses (EhV, Coccolithoviridae), for which information about its genomic properties has been detailed [75]. The virus-host interaction (EhV—E. huxleyi) has provided important information to understand early cellular and virus evolution [76]. Compared with the temperate counterpart, polar EhV have different genomic features such as hypervariable region and the presence of two specific tRNAs, a phosphate permease, an endonuclease and a transposase [75,77]. A remarkable feature in the EhVs genome is the presence of genes involved in metabolism (such as AMG), a feature thought to be present only in the hosts [78]. EhV have the ability to downregulate host genes involved in de novo sphingolipid biosynthesis of the host, while the viral genes involved in the same pathway are upregulated (e.g., serine palmitoyltransferase). These observations indicate that the virus hijacks the host sphingolipid biosynthesis functions [70]. All these metabolic changes help the virus control mortality of E. huxleyi, while evading the phytoplankton defense mechanisms [70,78]. For example, production of signaling lipids microdomains help with recognition of the virion by the E. huxleyi cell membrane; nonetheless, this mechanism also simultaneously ensures that the structural properties of the virions are protected from the environment in the north Atlantic, due to the multihydroxylated ceramide backbone membranes produced by the host [70].

Extreme viruses in eukaryotic microorganisms have also been described in geothermal lakes and soils [71,79]. The three-way mutualistic symbiotic relationship among the fungus Curvularia protuberata, the mycovirus Curvularia thermal tolerance virus (CThTV) and panic grass (Dichanthelium lanuginosum) allows all three organisms to survive in geothermal soils at $65^{\circ} \mathrm{C}$; an environment they would not survive in individually $[79,80]$. In fact, the absence of viral infection on C. protuberata leads to lack of thermotolerance by the plant and the fungus [80]. Other plant hosts have gained thermotolerance after being mixed with infected C. protuberata, pointing to the conserved nature of the resistance mechanism conferred by viruses to the host [79]. Genes in C. protuberata activated by CThTV are associated with the production of osmoprotectants, such as glycine betaine, taurine and trehalose. Additionally, scytalone dehydratase, a key enzyme in the melanin production pathway, increased 10-fold in the infected strains, pointing to a potential role of melanin on the fungus thermotolerance [79].

In the case of plants, those living under polar and drought conditions are the main source of currently described extremophile viruses. In polar conditions, an example are two viral entities isolated from 700-year-old caribou feces. The ancient caribou feces associated virus $(\mathrm{aCFV})$ and the ancient northwest territories cripavirus (aNCV) [81]. It has been suggested that those viruses could have originated from plant material consumed by the caribou from tundra environments. In fact, the authors successfully infected $N$. benthamiana with a cloned aCFV; the virus was able to replicate and spread systemically in the plant [81]. The sequences reported for this virus were significantly different from previously published 
viral sequences, indicating the unexplored nature of subarctic plant viruses (current and ancient) [81]. Table 5 summarizes the most relevant characteristics of these viruses.

Table 4. Virus in extremophile eukaryotic microorganism.

\begin{tabular}{|c|c|c|c|c|c|c|c|}
\hline Virus Type & Known Host & $\begin{array}{l}\text { Isolation } \\
\text { Origin }\end{array}$ & $\begin{array}{l}\text { Geographic } \\
\text { Range }\end{array}$ & $\begin{array}{l}\text { Genes or Molecular } \\
\text { Traits Followed }\end{array}$ & $\begin{array}{l}\text { Genome Size } \\
\text { and Other } \\
\text { Genetic Traits }\end{array}$ & $\begin{array}{l}\text { Accession } \\
\text { Numbers }\end{array}$ & References \\
\hline Eukaryotic viruses & $\begin{array}{c}\text { Algae } \\
\text { amoeba }\end{array}$ & Polar & Arctic & $\begin{array}{l}\text { Metagenomics } \\
\text { analysis }\end{array}$ & dsDNA & - & [72] \\
\hline $\begin{array}{l}\text { Micromonas } \\
\text { pusilla viruses } \\
(\mathrm{MpV})\end{array}$ & $\begin{array}{l}\text { Micromonas } \\
\text { pusilla }\end{array}$ & $\begin{array}{c}\text { Low } \\
\text { phosphorous } \\
\text { and polar }\end{array}$ & Arctic & DNApo) & dsDNA & - & [69] \\
\hline $\begin{array}{l}\text { Micromonas pusilla } \\
\text { viruses (MpV) } \\
\text { MpV-08T }\end{array}$ & $\begin{array}{l}\text { Micromonas } \\
\text { pusilla }\end{array}$ & $\begin{array}{c}\text { Low } \\
\text { phosphorous } \\
\text { and polar }\end{array}$ & Arctic & - & dsDNA & - & [74] \\
\hline $\begin{array}{l}\text { P. globose viruses } \\
\text { (PgV) PgV-07T }\end{array}$ & P. globosa & $\begin{array}{c}\text { Low } \\
\text { phosphorous } \\
\text { and polar }\end{array}$ & Arctic & - & dsDNA & - & [74] \\
\hline $\begin{array}{l}\text { Micromonas } \\
\text { pusilla viruses } \\
(\mathrm{MpV}) \\
\text { MpoV-44T, 45T, } \\
\text { 46T and 47T }\end{array}$ & $\begin{array}{l}\text { Micromonas } \\
\text { pusilla }\end{array}$ & Polar & Arctic & $\begin{array}{l}\text { DNA polymerase B } \\
\text { gene (polB) }\end{array}$ & $\begin{array}{c}\text { dsDNA } \\
205 \mathrm{kbp}, 191 \mathrm{kbp} \\
192 \mathrm{~kb}, 190 \mathrm{kbp}\end{array}$ & $\begin{array}{l}\text { ky682859 } \\
\text { to } \\
\text { ky682862 }\end{array}$ & [82] \\
\hline $\begin{array}{c}\text { Micromonas pusilla } \\
\text { viruses }(\mathrm{MpV}) \\
\text { MpV-08T }\end{array}$ & $\begin{array}{l}\text { Micromonas } \\
\text { pusilla }\end{array}$ & Polar & Arctic & $\begin{array}{l}\text { Viral major capsid } \\
\text { protein }\end{array}$ & dsDNA & - & [73] \\
\hline $\begin{array}{c}\text { Emiliania huxleyi } \\
\text { specific viruses } \\
\text { (EhVs) }\end{array}$ & $\begin{array}{l}\text { Emiliania } \\
\text { huxleyi }\end{array}$ & Polar & North Sea & MCP gene & dsDNA & $\begin{array}{c}\text { DQ084403 } \\
\text { to } \\
\text { DQ084406 }\end{array}$ & [83] \\
\hline $\begin{array}{c}\text { EhV-99B1 and } \\
\text { EhV86 }\end{array}$ & $\begin{array}{l}\text { Emiliania } \\
\text { huxleyi }\end{array}$ & Polar & $\begin{array}{l}\text { Norwegian } \\
\text { fjord }\end{array}$ & $\begin{array}{l}\text { EhV-86 phosphate } \\
\text { permease, } \\
\text { endonuclease CDS, } \\
\text { putative transposase } \\
\text { CDS, tRNAs }\end{array}$ & $\begin{array}{c}\text { dsDNA } \\
410 \mathrm{kbp} \\
160-180 \mathrm{~nm}\end{array}$ & FN429076 & [75] \\
\hline EhV & $\begin{array}{l}\text { Emiliania } \\
\text { huxleyi }\end{array}$ & Polar & $\begin{array}{l}\text { Norwegian } \\
\text { fjord }\end{array}$ & - & dsDNA & - & [84] \\
\hline $\begin{array}{l}\text { E. huxleyi lytic } \\
\text { virus EhV201 } \\
\text { Phycodnaviridae }\end{array}$ & $\begin{array}{l}\text { Emiliania } \\
\text { huxleyi }\end{array}$ & Polar & $\begin{array}{l}\text { Norwegian } \\
\text { fjord }\end{array}$ & $\begin{array}{l}\text { Sphingolipid } \\
\text { metabolism }\end{array}$ & - & - & [70] \\
\hline $\begin{array}{c}\text { Cafeteria } \\
\text { roenbergensis virus } \\
\text { (CroV), }\end{array}$ & $\begin{array}{c}\text { C. } \\
\text { roenbergensis } \\
\text { strain }\end{array}$ & Deep sea & & $\begin{array}{l}\text { Genome sequencing } \\
\text { DNA polymerase }\end{array}$ & $\begin{array}{l}\text { dsDNA } \\
730 \mathrm{~kb}\end{array}$ & GU244497 & [85] \\
\hline Coccolithoviruses & $\begin{array}{l}\text { Emiliania } \\
\text { huxleyi }\end{array}$ & Deep sea & Norway & $\begin{array}{c}\text { Metagenomic } \\
\text { analysis } \\
\text { Genes ehv452 and } \\
\text { ehv060 }\end{array}$ & $\begin{array}{l}\text { dsDNA virus } \\
\text { monopartite } \\
>350 \mathrm{kbp}\end{array}$ & PRJEB5540 & [77] \\
\hline $\begin{array}{l}\text { Curvularia thermal } \\
\text { tolerance virus }\end{array}$ & $\begin{array}{l}\text { Curvularia } \\
\text { protuberata }\end{array}$ & $\begin{array}{l}\text { Geothermal } \\
\text { soil }\end{array}$ & & qrtpcr & dsRNA & $\begin{array}{c}70403454 \\
\text { to } \\
70407660 .\end{array}$ & [79] \\
\hline
\end{tabular}


Table 4. Cont.

\begin{tabular}{|c|c|c|c|c|c|c|c|}
\hline Virus Type & Known Host & $\begin{array}{l}\text { Isolation } \\
\text { Origin }\end{array}$ & $\begin{array}{l}\text { Geographic } \\
\text { Range }\end{array}$ & $\begin{array}{l}\text { Genes or Molecular } \\
\text { Traits Followed }\end{array}$ & $\begin{array}{l}\text { Genome Size } \\
\text { and Other } \\
\text { Genetic Traits }\end{array}$ & $\begin{array}{l}\text { Accession } \\
\text { Numbers }\end{array}$ & References \\
\hline $\begin{array}{c}4 \text { Yellowstone Lake } \\
\text { virophages, }\end{array}$ & Algae & Geothermal & $\begin{array}{l}\text { Yellowstone } \\
\text { Lake }\end{array}$ & $\begin{array}{l}\text { Metagenomics } \\
\text { MCP, DNA } \\
\text { polymerase B family, } \\
\text { poxvirus late } \\
\text { transcription factor, } \\
\text { topoisomerase II, } \\
\text { vaccinia virus, } \\
\text { A32-like packaging } \\
\text { ATPase, } \\
\text { ribonucleotide } \\
\text { reductase small } \\
\text { subunit, multidrug } \\
\text { resistance protein, } \\
\text { OLV ORF2 }\end{array}$ & $\begin{array}{c}\text { dsDNA } \\
178 \mathrm{kbp}, 171 \mathrm{kbp}, \\
17 \mathrm{kbp}, 73 \mathrm{kbp}\end{array}$ & $\begin{array}{l}\text { LC015646- } \\
\text { LC015649 }\end{array}$ & [71] \\
\hline $\begin{array}{c}\text { Nucleocytoplasmic } \\
\text { large DNA viruses } \\
\text { (NCLDV) }\end{array}$ & $\begin{array}{l}\text { Different mi- } \\
\text { croorganisms }\end{array}$ & $\begin{array}{c}\text { Different } \\
\text { environments }\end{array}$ & In silico & $\begin{array}{c}\text { Bioinformatics } \\
\text { analysis } \\
\text { ATPases, NCLDV } \\
\text { ATPases and } \\
\text { polinton ATPases }\end{array}$ & $\begin{array}{c}\text { dsDNA } \\
100 \mathrm{kbp} \text { to } 2.50 \\
\mathrm{Mbp}\end{array}$ & - & [86] \\
\hline $\begin{array}{l}\text { Yellowstone Lake } \\
\text { virophages } \\
\text {-YSLV5, YSLV6 } \\
\text { and YSLV7 }\end{array}$ & $\begin{array}{l}\text { Giant DNA } \\
\text { viruses and } \\
\text { eukaryotic } \\
\text { hosts }\end{array}$ & Geothermal & $\begin{array}{l}\text { Yellowstone } \\
\text { Lake }\end{array}$ & $\begin{array}{c}\text { Metagenomics } \\
\text { ATPase, MCP and } \\
\text { Pro }\end{array}$ & $\begin{array}{c}\text { cdsDNA } \\
30 \mathrm{kbp}, 25 \mathrm{kbp}, \\
24 \mathrm{kbp}\end{array}$ & $\begin{array}{l}\text { KM502589 } \\
\text { to } \\
\text { KM502591 }\end{array}$ & [87] \\
\hline $\begin{array}{c}\text { Organic Lake } \\
\text { virophage (OLV) }\end{array}$ & $\begin{array}{c}\text { Acanthamoeba } \\
\text { polyphaga } \\
\text { Acanthamoeba } \\
\text { polyphaga } \\
\text { mimivirus } \\
\text { (APMV) }\end{array}$ & $\begin{array}{l}\text { Polar } \\
\text { hypersaline } \\
\text { meromictic } \\
\text { lake }\end{array}$ & $\begin{array}{l}\text { Antarctica } \\
\text { Organic } \\
\text { Lake }\end{array}$ & $\begin{array}{c}\text { Metagenomics } \\
\text { MCP }\end{array}$ & $\begin{array}{l}\text { cdsDNA } \\
18 \mathrm{kbp}\end{array}$ & $\begin{array}{l}\text { HQ704801 } \\
\text { to } \\
\text { HQ704808 }\end{array}$ & [88] \\
\hline
\end{tabular}

Table 5. Virus in extremophile plants.

\begin{tabular}{|c|c|c|c|c|c|c|c|}
\hline Virus Type & Known Host & $\begin{array}{c}\text { Extreme } \\
\text { Environment }\end{array}$ & $\begin{array}{c}\text { Geographic } \\
\text { Range }\end{array}$ & $\begin{array}{c}\text { Genes or } \\
\text { Molecular Traits } \\
\text { Followed }\end{array}$ & $\begin{array}{c}\text { Genome Size } \\
\text { and Other } \\
\text { Genetic Traits }\end{array}$ & $\begin{array}{l}\text { Accession } \\
\text { Numbers }\end{array}$ & References \\
\hline $\begin{array}{l}\text { Ancient caribou } \\
\text { feces associated } \\
\text { virus }(\mathrm{aCFV})\end{array}$ & - & Polar & $\begin{array}{c}\text { Arctic } \\
\text { environment }\end{array}$ & Rep proteins & $\begin{array}{c}\text { small circular } \\
\text { ssDNA } \\
2.2 \mathrm{~kb}\end{array}$ & KJ938716 & [81] \\
\hline $\begin{array}{c}\text { Ancient } \\
\text { Northwest } \\
\text { Territories } \\
\text { cripavirus } \\
\text { (aNCV) }\end{array}$ & - & Polar & $\begin{array}{c}\text { Arctic } \\
\text { environment }\end{array}$ & $\begin{array}{l}\text { RNA-dependent } \\
\text { RNA polymerase }\end{array}$ & $\begin{array}{l}\text { ssRNA } \\
1.8 \mathrm{~kb}\end{array}$ & KJ938718 & [81] \\
\hline $\begin{array}{l}\text { Turnip mosaic } \\
\text { virus (TuMV) }\end{array}$ & $\begin{array}{c}\text { Arabidopsis } \\
\text { (Arabidopsis } \\
\text { thaliana) }\end{array}$ & Drought & - & $\begin{array}{l}\text { Transcriptome } \\
\text { and metabolome }\end{array}$ & $(+) \operatorname{ssRNA}$ & GSE46760 & [89] \\
\hline $\begin{array}{l}\text { Cauliflower } \\
\text { mosaic virus } \\
(\text { CaMV })\end{array}$ & $\begin{array}{c}\text { Turnip } \\
\text { (Brassica rapa } \\
\text { cv. 'Just Right') }\end{array}$ & Drought & - & Ca4443 & dsDNA & - & [90] \\
\hline $\begin{array}{l}\text { Turnip mosaic } \\
\text { virus (TuMV) }\end{array}$ & $\begin{array}{c}\text { Turnip } \\
\text { (Brassica rapa } \\
\text { cv. 'Just Right') }\end{array}$ & Drought & - & Tu8907 & $(+)$ ssRNA & - & [90] \\
\hline
\end{tabular}

\section{Biotechnological Potential}

The growing interest on the molecular dynamics of extremophiles and their viruses resides mainly on the premise that understanding these systems will improve understanding protein folding, stability, protein-protein interactions and even, the influence viruses have on host evolution [38]. 
The number of viral genome sequencing projects reported to date, July 2020, in the National Center for Biotechnology Information (NCBI) Genome database indicated that 9735 viral genomes have been sequenced where 2929 were isolated from bacteria, 89 from archaea, 39 from eukaryotic algae, 272 from fungi, 40 from protozoa and 1823 from land plants [91,92]. However, the genomic potential of the viral genomes sequenced up to date, particularly, of extremophile viruses, for biotechnological applications remains a largely unexplored subject [5]. Extremophile organisms (bacteria and archaea) have shown to be a very rich source of thermostable enzymes with industrial applications, going from polymerase for molecular biology to lipases and proteases in detergents for processes that take place at extreme conditions, such as high or low temperatures and $\mathrm{pH}$ and the production of biopolymers [93,94]. Enzymes from extremophile viruses will have a critical role in complementing such processes and finding new niches (Figure 1).

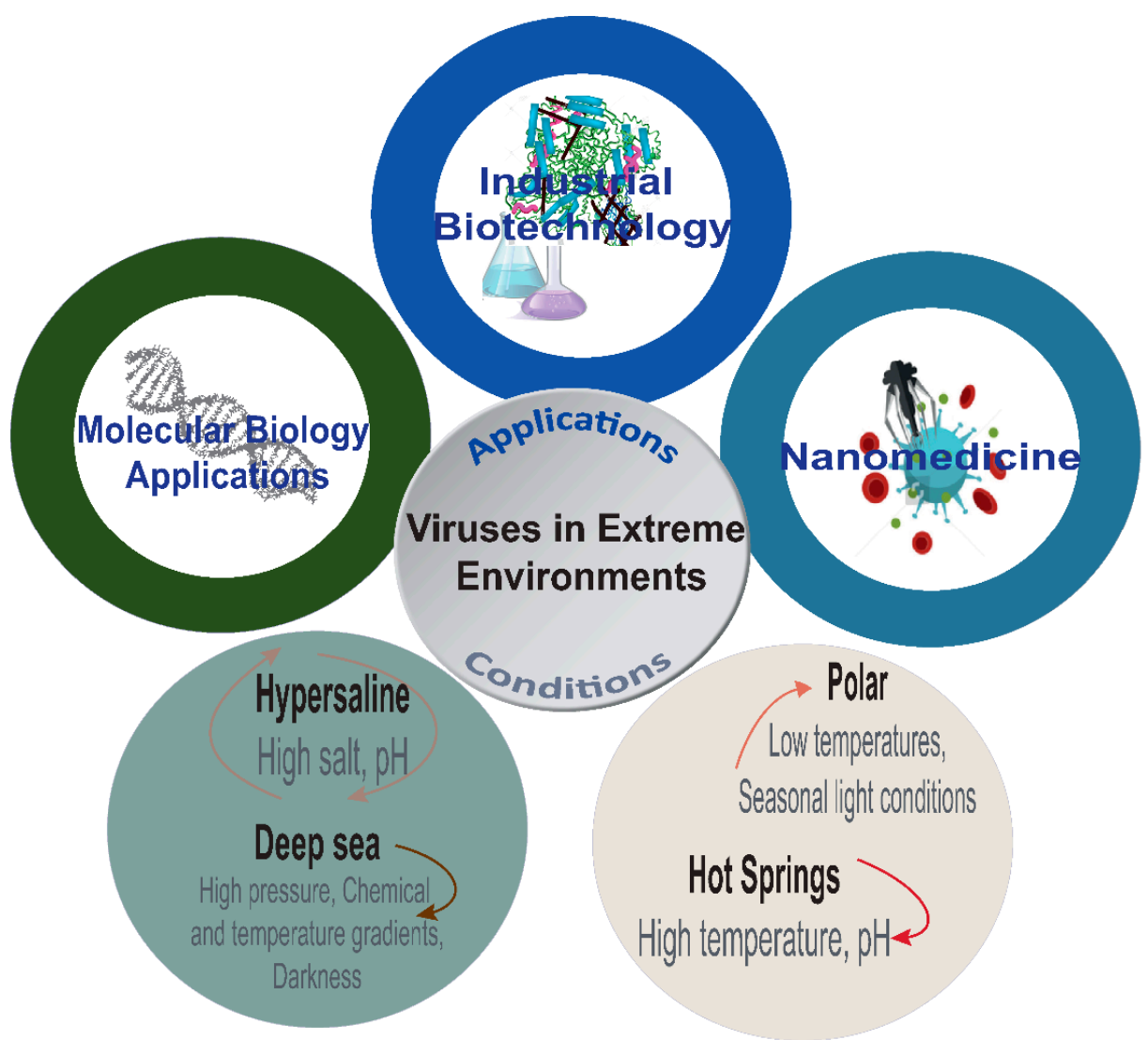

Figure 1. Main features of the extreme conditions and potential applications of extremophile viruses. Physical and chemical characteristics modeling the different environments and the potential biotechnological applications of viruses including molecular biology applications, nano-medicine and drug delivery and industrial biotechnology.

\subsection{Molecular Biology}

Environmental sampling in tandem with recent advances in sequencing methodologies, meta-OMICS and isolation techniques have brought to light novel discoveries in virology, particularly in extremophile organisms, that were almost inaccessible in the past (e.g., endocytobiont pandoravirus [95]). The appeal of extremophile viruses relies on their particular ability to adapt to difficult environments and the molecular mechanisms that allow them to bypass their hosts' defense strategies, hence, being successful at replicating and producing stable virions in these harsh conditions. To that end, extremophile viruses may use a broad variety of tools such as integrases (e.g., SNJ2) [96], which have rapidly gain prominence as genetic tools including, cloning, genome engineering and synthetic biology [97-99]. These enzymes can provide an efficient integration of large 
DNA fragments with different recognition sites and integration mechanisms, which can be utilized to transform microorganisms that are not responsive to standard molecular genetic methods [98].

Reverse transcription (RT) is one of the most important in vitro tools in RNA studies (viral, RNA expression, mRNA biomarkers, non-coding RNAs, etc.), prior further manipulation as copy DNA (cDNA). Currently, RT is done using mesostable enzymes from Moloney murine leukemia virus (MMLV) and avian myeloblastosis virus (AMV). The lack of thermostability of the enzymes limits the detection of certain molecules that have more complicated secondary structures and require higher temperatures for denaturation such as hairpins, stem loops and G quadruplexes, highly structure RNA targets, viral RNA genomes (reviewed in [99]). Screening of thermophilic viral metagenomes has allowed the identification of PyroPhage Pol thermostable enzyme that can be used for both RT and PCR reactions $[100,101]$. The novel characteristics of the enzyme, along with viral metagenomic information summed to protein engineering resulted in variants of enzymes with novel modified traits [102]. Thus, there is potential in extremophile viral genomes for discovery of new enzymes to be explored and engineered for further applications in molecular biology.

Single-stranded DNA binding (SSB) proteins are ubiquitous across all three domains of life and are found in many viruses, playing essential roles in genome maintenance, DNA replication, recombination, repair and transcription. SSB have been detected in archaeal virus SIRV2. SIRV2 operon containing three genes, gp17, gp18 and gp19 that are highly conserved in rudiviruses and filamentous viruses. gp17 is a SSB protein and differs in structure from the classical SSB, and thus constitutes a novel non-canonical ssDNA binding protein (Guo, Kragelund, White and Peng 2015).

Nucleases have also been found from viromes obtained from acidic hot springs $\left(>85^{\circ} \mathrm{C}\right.$ and $\mathrm{pH}<3$ ) of Yellowstone National Park. Acidianus filamentous virus 1 (AFV1) is an enveloped filamentous virus that infects Acidianus species. ORF157 reveals a 157-residue protein that exhibits in vitro nuclease activity that degrades linear dsDNA, and an E86 residue essential for the nuclease activity [103].

DNA polymerases have been also detected in extreme viruses inhabiting circumneutral and alkaline hot springs in Yellowstone National Park and US Great Basin. Bioinformatics and functional screens studies revealed a group of family A-type DNA polymerase (polA) genes. The proteins encoded by these viral polA genes were remarkably similar to polymerases found in the bacterial phylum Aquificae and the eukaryotic phylum Apicomplexa and invoke a key role of thermophilic viruses in lateral transfer of these polymerase genes which suggests that these genes may be associated with dispersal of diversity-generating mechanisms between geothermal and moderate-temperature biomes [104]. Other polymerases have been detected in extreme metaviromes, particularly from hypoxic estuarine waters obtained in the Gulf of Maine, Dry Tortugas National Park and the Chesapeake Bay (Andrews-Pfannkoch, Fadrosh, Thorpe and Williamson 2010; Schmidt, Sakowski, Williamson, Polson and Wommack 2014).

\subsection{Nanomedicine and Drug Delivery}

At present, there is increasing interest in identifying archaeal viral species with potential for new medical nano-platforms. Viruses such as Sulfolobus monocaudavirus 1 (SMV1) and Sulfolobus spindle-shaped virus 2 (SSV2) can be efficiently internalized into human cell lines without causing lytic damage; interacting with elements of the innate immune system, and working as activating complementarity $[105,106]$. Due to their novel biophysical properties, archaeal viruses are becoming increasingly important for research in the fields of bioengineering and nano-therapeutic developments [106]. The discoveries in this regard open new opportunities for studying infection processes, as well as vaccine formulation. Viral-like particles can work as B lymphocyte activators, with additional modification of some of the amino acid residues (lysine, aspartic acid and glutamate) with antigens. A similar approach can also consider to produce cellular biosensor (reviewed 
in [106]). Furthermore, studying the potato virus X (PVX) has proven beneficial to develop tools used in molecular imaging, tumor homing, drug delivery, vaccination, biosensor design, biomaterials development and biocatalysts [107]. Thus, virus nanoparticles are receiving more and more attention due to their outstanding structural characteristics and ease of functionalization compared to synthetic nanoparticles.

Currently, there is no information that explains the apparent absence of cellular receptors in archaeal viruses, or none has been identified so far. However, there are reports describing the binding of archaeal viruses to extracellular structures such as pili. For instance, Sulfolobus islandicus rod-shaped virus 2 (SIRV2), binds to the tips of the pili, with ulterior movement to the cell along the pili. This phenomenon supports the notion that extremophile viruses, and in particular thermophilic viruses, have developed a system to reduce their time outside the cell (reviewed in [21]). This type of movement and cell recognition by the virus virions, has a potential use in virus-like nanoparticles for delivery of molecules of interest in different models. In this process, virions do not contain genetic information (genomic DNA or RNA), instead a molecule of interest (e.g., drug) is carried inside. These virus-like nanoparticles are then delivered and bound specifically to the target cell(s). This approach can be used in increasing the specificity on cancer treatments as the virus-like nanoparticle will only interact with a specific type of cell.

In recent years, in the biopharmaceutical and molecular diagnostics areas, lytic enzymes have gained increasing importance due to their potential use as new strategies against antibiotic-resistant bacterial pathogens in the current age of mounting antibiotic resistance. A number of enzymes have been identified using sequencing-based screens from extremophile viromes, among them, lysin-like genes have been identified from two mildly alkaline hot springs in Yellowstone [5,108]. Endolysins or lysins are phage-encoded enzymes capable of hydrolyzing the bacterial cell wall and are synthesized at the end of the phage replication cycle (Vázquez, García and García, 2018).

For example, from a whole genome study of Thermus phage TSP4 isolated from Tengchong hot spring in Yunnan Province of China at a temperature of $70^{\circ} \mathrm{C}$ with a pH of 7.0, was identified a novel phage lysin named TSPphg and assessed in vitro and in vivo its antibacterial activity against a panel of antibiotic-resistant strains. TSPphg is able to cause bacteria destruction and has shown bactericidal activity against both Gram-negative and Gram-positive pathogenic bacteria, especially antibiotic-resistant strains of Klebsiella pneumoniae [109].

Recently, the first crystal structure of an endolysin (Ts2631) from a thermophilic bacteriophage vB_Tsc2631 isolated from a hot spring of the Hverager geothermal area, Iceland has been reported. The analysis of the structure and sequence of a Ts2631 revealed that it contains a unique $\mathrm{N}$-terminal sequence that is not found in the phage homologs, a 20 residue extension at the $\mathrm{N}$-terminus with a unique motif rich in arginines that is not homologous to any other protein sequence present in the UniProt database and that can protrude from the remainder of the enzyme and is crucial for peptidoglycan binding. Using this unique $\mathrm{N}$-terminal sequence for the design of fusion proteins might become a platform for the development of novel protein antibiotics targeting Gram-negative bacteria [110].

\subsection{Industrial Biotechnology}

Viruses infecting microalgae are responsible for controlling their bloom in the Arctic and Antarctic oceans [74,82]. Due to their ability to control lysis and thus mortality of micro eukaryotes, this property can be explored to produce controlled lysis in industrial cultures of microalgae, for example, for production of biofuels. Viruses in the algae lysis cycle can be controlled via nutrient concentration (e.g., $\mathrm{CO}_{2}$, Phosphorus) [111] and activated when the algae production reaches the desired concentration. This approach requires the evaluation of viruses able to lyse commercial species of microalgae and/or their modification (engineering) to the desired effect.

Extracellular polymeric substances (EPS) are produced by different types of microorganisms, in response to environmental stress. As evidenced by different psychrophilic 
bacteria, EPS production is not only used as cryoprotectant, but also as a defense mechanism against viral attacks [112]. If it is possible to modulate the production of EPS by the presence or absence of viral markers, EPS could be produced in high concentrations and yield, scaling up its production for biotechnological applications with economic feasibility. In this sense, the study of virus-host interactions to enhance EPS expression can be a game changer for EPS industrial and medical applications such as bioplastics, scaffold materials for tissue culture and biomedical polymers [112-114].

Another potential application is the use of enzymes able to perform in extreme conditions such as endolysin/lysozyme. Some of those have been described in viruses from extreme environments. These enzymes could be used for treating fouling of filters created by bacterial growth [82]. The potential use of these extremophile enzymes is even more relevant considering that some of these filters are used in environments with extreme $\mathrm{pH}$ and salt concentrations [115] which requires the use of enzymes that are fully active at such conditions. It is noteworthy to mention that their effectiveness against microbes have been successfully proven [111]. Phage endolysins have shown a wide range of activity in both high salt environments $(100 \%$ activity at $500 \mathrm{mM} \mathrm{NaCl}$ for Pseudomonas aeruginosa-infecting phage fKZ) and high temperatures (activity over $94 \%$ at 50 to $78{ }^{\circ} \mathrm{C}$ in $\mathrm{Ph} 2119$ ) (reviewed in [112]).

Bacteriophage 9A has several identified enzymatic traits (AMGs) that guarantee activity at low temperature of the host (reviewed in [56]). Thus, the continuous discovery of thermostable enzymes might expand its use for biotechnological processes taking place at extreme temperatures, where specific enzymes functions are desired. Such is the case of studied thermophilic enzymes of great importance to the breakdown of biomass and other materials such as waste plastics [116]. Equally important is the use of psychrophilic enzymes in industrial processes, where instability issues with reactants and products can be avoided by such enzymes, allowing a reduction in costs. This property is due to their lower energy consumption and their high catalytic efficiency [113]. Examples of these are an l-aminoaceylase and a $\gamma$-lactamase. Industrial applications of other enzymes such as transaminases, carbonic anhydrases, dehalogenases, esterases and epoxide hydrolases are also being assessed [113].

\section{Prospectus}

Here, we presented an overview of what is known about viruses in extreme environments, highlighting their diversity and the molecular mechanisms that allow them to form complex, symbiotic relationships with a variety of prokaryotic and eukaryotic hosts. Of note, we highlighted the role viruses play in regulating population dynamics in the different ecosystems on earth, mainly those in inhabiting the oceans. We believe that expanding this area of knowledge would result in a more accurate depiction of viral ecology and its biotechnological potential in extreme environments.

Although new sequencing technologies, as well as sampling methods have facilitated the understanding of the genomics and metabolic mechanisms characterizing viruses in extreme environments, there is still significant knowledge gaps on the dynamics and biological processes of these viruses at a global scale. An example of this limitation is the omission of studies of viruses in the equatorial zone of the world (Africa and Latin America) (Figure 2). For instance, out of 114 reviewed articles on viruses from extreme environments, 109 have been originated from regions in temperate and fridge zones, in fact, USA and Europe contribute to $75 \%$ of the reported studied areas. In contrast, despite the presence of 174 volcanic environments in the South American Andes (soil, lakes and hot springs) [117], only 5 reports originate from countries in the equatorial zone, and 0 from continental South America. This unexplored viral diversity provides a unique opportunity to study the extremophile viruses of bacteria, archaea and eukaryotic organisms as novel sources of viruses and viral enzymes with biotechnological potential. Studies in virology in these places can bring new insight about the role viruses have in shaping biodiversity in the equatorial zone, providing an opportunity to develop collaborative research efforts 
with scientists worldwide to establish a catalogue of extreme viruses and their genomic potential in understudied regions of the world [114,118].

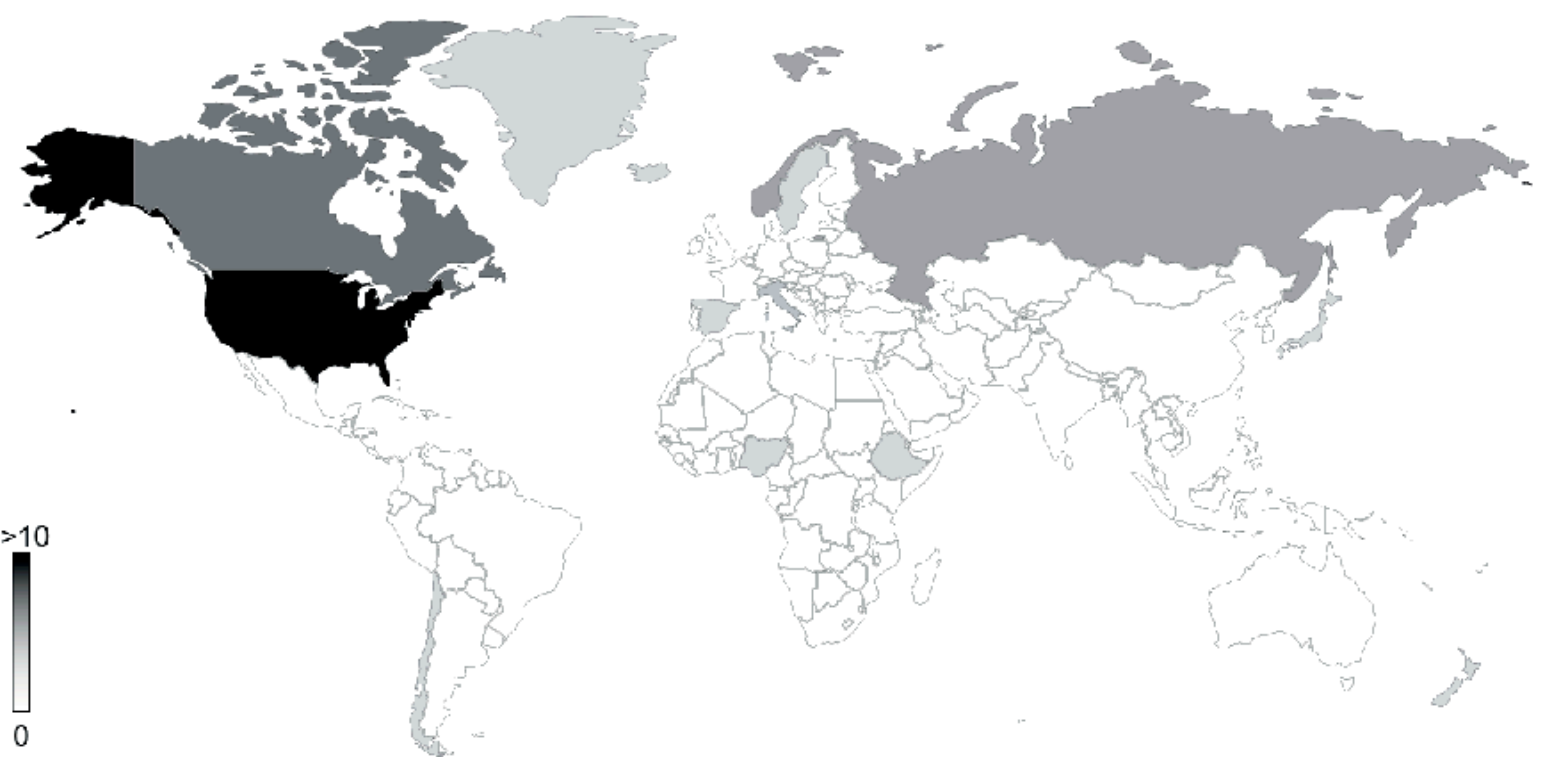

Figure 2. World heat map of virus detected in extreme environments. Locations are colored (gray scale) according to the amount of reviewed literature originating from specific country. Locations are shown by country and represented with a grey scale.

Funding: This research received no external funding.

Conflicts of Interest: The authors declare no conflict of interest.

\section{References}

1. Rampelotto, P.H. Extremophiles and extreme environments. Life 2013, 3, 482-485. [CrossRef] [PubMed]

2. Singh, P.; Jain, K.; Desai, C.; Tiwari, O.; Madamwar, D. Microbial community dynamics of extremophiles/extreme environment. In Microbial Diversity in the Genomic Era; Elsevier BV: Amsterdam, The Netherlands, 2019; pp. 323-332.

3. Lindgren, A.R.; Buckley, B.A.; Eppley, S.M.; Reysenbach, A.-L.; Stedman, K.M.; Wagner, J.T. Life on the edge-The biology of organisms inhabiting extreme environments: An introduction to the Symposium. Integr. Comp. Biol. 2016, 56, 493-499. [CrossRef] [PubMed]

4. Krupovic, M.; Dolja, V.V.; Koonin, E.V. Origin of viruses: Primordial replicators recruiting capsids from hosts. Nat. Rev. Microbiol. 2019, 17, 449-458. [CrossRef] [PubMed]

5. Dávila-Ramos, S.; Castelán-Sánchez, H.G.; Martínez-Ávila, L.; Sánchez-Carbente, M.D.R.; Peralta, R.; Hernández-Mendoza, A.; Dobson, A.D.W.; Gonzalez, R.A.; Pastor, N.; Batista-García, R.A. A review on viral metagenomics in extreme environments. Front. Microbiol. 2019, 10, 2403. [CrossRef] [PubMed]

6. Mesa, V.; Gallego, J.L.R.; González-Gil, R.; Lauga, B.; Sánchez, J.; Méndez-García, C.; Peláez, A.I. Bacterial, Archaeal, and Eukaryotic Diversity across Distinct Microhabitats in an Acid Mine Drainage. Front. Microbiol. 2017, 8, 1756. [CrossRef] [PubMed]

7. Cowan, D.; Ramond, J.-B.; Makhalanyane, T.; De Maayer, P.; Cowan, D.A.; Makhalanyane, T.P. Metagenomics of extreme environments. Curr. Opin. Microbiol. 2015, 25, 97-102. [CrossRef] [PubMed]

8. Amils, R.; Ellis-Evans, C.; Hinghofer-Szalkay, H. Life in Extreme Environments; Springer: New York, NY, USA, 2007.

9. Zablocki, O.; Adriaenssens, E.M.; Cowan, D.A. Diversity and ecology of viruses in hyperarid desert soils. Appl. Environ. Microbiol. 2016, 82, 770-777. [CrossRef]

10. Krupovic, M.; Prangishvili, D.; Hendrix, R.W.; Bamford, D.H. Genomics of bacterial and archaeal viruses: Dynamics within the prokaryotic virosphere. Microbiol. Mol. Biol. Rev. 2011, 75, 610-635. [CrossRef]

11. Danovaro, R.; Rastelli, E.; Corinaldesi, C.; Tangherlini, M.; Dell'Anno, A. Marine archaea and archaeal viruses under global change. F1000Research 2017, 6, 1241. [CrossRef]

12. Krupovic, M.; Cvirkaite-Krupovic, V.; Iranzo, J.; Prangishvili, D.; Koonin, E.V. Viruses of archaea: Structural, functional, environmental and evolutionary genomics. Virus Res. 2018, 244, 181-193. [CrossRef]

13. López-García, P.; Zivanovic, Y.; Deschamps, P.; Moreira, D. Bacterial gene import and mesophilic adaptation in archaea. Nat. Rev. Microbiol. 2015, 13, 447-456. [CrossRef] [PubMed] 
14. Nelson-Sathi, S.; Sousa, F.L.; Roettger, M.; Lozada-Chávez, N.; Thiergart, T.; Janssen, A.; Bryant, D.; Landan, G.; Schönheit, P.; Siebers, B.; et al. Origins of major archaeal clades correspond to gene acquisitions from bacteria. Nat. Cell Biol. 2015, 517, 77-80. [CrossRef] [PubMed]

15. Groussin, M.; Boussau, B.; Szöllõsi, G.; Eme, L.; Gouy, M.; Brochier-Armanet, C.; Daubin, V. Gene acquisitions from bacteria at the origins of major archaeal clades are vastly overestimated. Mol. Biol. Evol. 2016, 33, 305-310. [CrossRef] [PubMed]

16. Garcia-Vallvé, S.; Romeu, A.; Palau, J. Horizontal gene transfer in bacterial and archaeal complete genomes. Genome Res. 2000, 10, 1719-1725. [CrossRef] [PubMed]

17. Lurie-Weinberger, M.N.; Gophna, U. Archaea in and on the human body: Health implications and future directions. PLoS Pathog. 2015, 11, e1004833. [CrossRef] [PubMed]

18. Coutinho, F.H.; Edwards, R.A.; Rodríguez-Valera, F. Charting the diversity of uncultured viruses of Archaea and Bacteria. BMC Biol. 2019, 17, 109. [CrossRef]

19. Danovaro, R.; Dell'Anno, A.; Corinaldesi, C.; Rastelli, E.; Cavicchioli, R.; Krupovic, M.; Noble, R.T.; Nunoura, T.; Prangishvili, D. Virus-mediated archaeal hecatomb in the deep seafloor. Sci. Adv. 2016, 2, e1600492. [CrossRef]

20. Stedman, K.M.; Porter, K.; Dyall-Smith, M. The isolation of viruses infecting Archaea. In Manual of Aquatic Viral Ecology; Wiley: Hoboken, NJ, USA, 2010; pp. 57-64.

21. Munson-McGee, J.H.; Snyder, J.C.; Young, M.J. Archaeal viruses from high-temperature environments. Genes 2018, 9, 128. [CrossRef]

22. Prangishvili, D.; Bamford, D.H.; Forterre, P.; Iranzo, J.; Koonin, E.V.; Krupovic, M. The enigmatic archaeal virosphere. Nat. Rev. Microbiol. 2017, 15, 724-739. [CrossRef]

23. Rensen, E.I.; Mochizuki, T.; Quemin, E.; Schouten, S.; Krupovic, M.; Prangishvili, D. A virus of hyperthermophilic archaea with a unique architecture among DNA viruses. Proc. Natl. Acad. Sci. USA 2016, 113, 2478-2483. [CrossRef]

24. Stedman, K.M.; Deyoung, M.; Saha, M.; Sherman, M.B.; Morais, M.C. Structural insights into the architecture of the hyperthermophilic Fusellovirus SSV1. Virology 2015, 474, 105-109. [CrossRef] [PubMed]

25. Prangishvili, D.; Vestergaard, G.; Häring, M.; Aramayo, R.; Basta, T.; Rachel, R.; Garrett, R.A. Structural and genomic properties of the hyperthermophilic archaeal virus ATV with an extracellular stage of the reproductive cycle. J. Mol. Biol. 2006, 359, 1203-1216. [CrossRef] [PubMed]

26. Gudbergsdottir, S.; Menzel, P.; Krogh, A.; Young, M.J.; Peng, X. Novel viral genomes identified from six metagenomes reveal wide distribution of archaeal viruses and high viral diversity in terrestrial hot springs. Environ. Microbiol. 2016, 18, 863-874. [CrossRef] [PubMed]

27. Wagner, C.; Reddy, V.; Asturias, F.; Khoshouei, M.; Johnson, J.E.; Manrique, P.; Munson-McGee, J.; Baumeister, W.; Lawrence, C.M.; Young, M.J. Isolation and characterization of metallosphaera turreted icosahedral virus, a founding member of a new family of archaeal viruses. J. Virol. 2017, 91, e00925-17. [CrossRef] [PubMed]

28. Jaatinen, S.; Happonen, L.; Laurinmäki, P.; Butcher, S.; Bamford, D. Biochemical and structural characterisation of membranecontaining icosahedral dsDNA bacteriophages infecting thermophilic Thermus thermophilus. Virology 2008, 379, 10-19. [CrossRef]

29. DiMaio, F.; Yu, X.; Rensen, E.; Krupovic, M.; Prangishvili, D.; Egelman, E.H. A virus that infects a hyperthermophile encapsidates A-form DNA. Science 2015, 348, 914-917. [CrossRef] [PubMed]

30. Atanasova, N.S.; Roine, E.; Oren, A.; Bamford, D.H.; Oksanen, H.M. Global network of specific virus-host interactions in hypersaline environments. Environ. Microbiol. 2012, 14, 426-440. [CrossRef]

31. Demina, T.A.; Pietilä, M.K.; Svirskaitè, J.; Ravantti, J.J.; Atanasova, N.S.; Bamford, D.H.; Oksanen, H.M. HCIV-1 and other tailless icosahedral internal membrane-containing viruses of the family Sphaerolipoviridae. Viruses 2017, 9, 32. [CrossRef] [PubMed]

32. Hulo, C.; De Castro, E.; Masson, P.; Bougueleret, L.; Bairoch, A.; Xenarios, I.; Le Mercier, P. ViralZone: A knowledge resource to understand virus diversity. Nucleic Acids Res. 2011, 39, D576-D582. [CrossRef]

33. Snyder, J.C.; Bolduc, B.; Young, M.J. 40 Years of archaeal virology: Expanding viral diversity. Virology 2015, 479-480, 369-378. [CrossRef]

34. Prangishvili, D. The wonderful world of archaeal viruses. Annu. Rev. Microbiol. 2013, 67, 565-585. [CrossRef] [PubMed]

35. Télesphore Simengando, P.; Chapron, E.; Jézéquel, D. Lake Pavin: A pioneer site for ecological studies of freshwater viruses. In Lake Pavin History, Geology, Biogeochemistry, and Sedimentology of a Deep Meromictic Maar Lake; Springer International Publishing Switzerland: Cham, Switzerland, 2016; pp. 229-244.

36. Chien, I.-C.; Meschke, J.S.; Gough, H.L.; Ferguson, J.F. Characterization of persistent virus-like particles in two acetate-fed methanogenic reactors. PLoS ONE 2013, 8, e81040. [CrossRef] [PubMed]

37. ICTV-International Commitee on Taxonomy. Virus Taxonomy: 9th Report of the International Committee on Taxonomy of Viruses-Part II: The Viruses-Family Birnaviridae; ICTV: Berlin, Germany, 2012.

38. Goodman, D.A.; Stedman, K.M. Comparative genetic and genomic analysis of the novel Fusellovirus Sulfolobus spindle-shaped virus 10. Virus Evol. 2018, 4, vey022. [CrossRef] [PubMed]

39. Iverson, E.A.; Goodman, D.A.; Gorchels, M.E.; Stedman, K.M. Extreme mutation tolerance: Nearly half of the archaeal fusellovirus sulfolobus spindle-shaped virus 1 genes are not required for virus function, including the minor capsid protein gene vp3. J. Virol. 2017, 91, e02406-16. [CrossRef] [PubMed]

40. Dar, D.; Sorek, R. Bacterial noncoding RNAs excised from within protein-coding transcripts. mBio 2018, 9, e01730-18. [CrossRef] 
41. Wang, F.; Baquero, D.P.; Beltran, L.C.; Su, Z.; Osinski, T.; Zheng, W.; Prangishvili, D.; Krupovic, M.; Egelman, E.H. Structures of filamentous viruses infecting hyperthermophilic archaea explain DNA stabilization in extreme environments. Proc. Natl. Acad. Sci. USA 2020, 117, 19643-19652. [CrossRef]

42. Larson, E.T.; Eilers, B.J.; Reiter, D.; Ortmann, A.C.; Young, M.J.; Lawrence, C.M. A new DNA binding protein highly conserved in diverse crenarchaeal viruses. Virology 2007, 363, 387-396. [CrossRef]

43. Shapiro, J.W.; Putonti, C. Gene co-occurrence networks reflect bacteriophage ecology and evolution. mBio 2018, 9, e01870-17. [CrossRef]

44. Wang, Y.; Zhang, X. Genome analysis of deep-sea thermophilic phage D6E. Appl. Environ. Microbiol. 2010, 76, 7861-7866. [CrossRef]

45. Ackermann, H.-W. Frequency of morphological phage descriptions in the year 2000. Arch. Virol. 2001, 146, 843-857. [CrossRef]

46. Middelboe, M.; Brussaard, C. (Corina) marine viruses: Key players in marine ecosystems. Viruses 2017, 9, 302. [CrossRef] [PubMed]

47. De Corte, D.; Sintes, E.; Yokokawa, T.; Reinthaler, T.; Herndl, G.J. Links between viruses and prokaryotes throughout the water column along a North Atlantic latitudinal transect. ISME J. 2012, 6, 1566-1577. [CrossRef] [PubMed]

48. Enagayoshi, Y.; Ekumagae, K.; Emori, K.; Etashiro, K.; Enakamura, A.; Efujino, Y.; Ehiromasa, Y.; Eiwamoto, T.; Ekuhara, S.; Eohshima, T.; et al. Physiological properties and genome structure of the hyperthermophilic filamentous phage $\varphi \mathrm{OH} 3$ which infects thermus thermophilus HB8. Front. Microbiol. 2016, 7, 50. [CrossRef]

49. Krupovic, M.; Dutilh, B.E.; Adriaenssens, E.M.; Wittmann, J.; Vogensen, F.K.; Sullivan, M.B.; Rumnieks, J.; Prangishvili, D.; Lavigne, R.; Kropinski, A.M.; et al. Taxonomy of prokaryotic viruses: Update from the ICTV bacterial and archaeal viruses subcommittee. Arch. Virol. 2016, 161, 1095-1099. [CrossRef]

50. Liu, B.; Wu, S.; Song, Q.; Zhang, X.; Xie, L. Two novel bacteriophages of thermophilic bacteria isolated from deep-sea hydrothermal fields. Curr. Microbiol. 2006, 53, 163-166. [CrossRef]

51. Marks, T.J.; Hamilton, P.T. Characterization of a thermophilic bacteriophage of Geobacillus kaustophilus. Arch. Virol. 2014, 159, 2771-2775. [CrossRef]

52. Yu, M.X.; Slater, M.R.; Ackermann, H.-W. Isolation and characterization of Thermus bacteriophages. Arch. Virol. 2006, 151, 663-679. [CrossRef]

53. Atanasova, N.S.; Oksanen, H.M.; Bamford, D.H. Haloviruses of archaea, bacteria, and eukaryotes. Curr. Opin. Microbiol. 2015, 25, 40-48. [CrossRef]

54. Tapia, P.; Flores, F.M.; Covarrubias, P.C.; Acuña, L.G.; Holmes, D.S.; Quatrini, R. Complete genome sequence of temperate bacteriophage AcaML1 from the extreme acidophile acidithiobacillus caldus ATCC 51756. J. Virol. 2012, 86, 12452-12453. [CrossRef]

55. Borriss, M.; Helmke, E.; Hanschke, R.; Schweder, T. Isolation and characterization of marine psychrophilic phage-host systems from Arctic sea ice. Extremophiles 2003, 7, 377-384. [CrossRef]

56. Colangelo-Lillis, J.R.; Deming, J.W. Genomic analysis of cold-active Colwelliaphage 9A and psychrophilic phage-host interactions. Extremophiles 2013, 17, 99-114. [CrossRef] [PubMed]

57. Calvo, C.; De La Paz, A.G.; Béjar, V.; Quesada, E.; Ramos-Cormenzana, A. Isolation and characterization of phage F9-11 from a lysogenicDeleya halophila strain. Curr. Microbiol. 1988, 17, 49-53. [CrossRef]

58. Seaman, P.F.; Day, M. Isolation and characterization of a bacteriophage with an unusually large genome from the Great Salt Plains National Wildlife Refuge, Oklahoma, USA. FEMS Microbiol. Ecol. 2007, 60, 1-13. [CrossRef] [PubMed]

59. Van Zyl, L.J.; Nemavhulani, S.; Cass, J.; Cowan, D.A.; Trindade, M. Three novel bacteriophages isolated from the East African Rift Valley soda lakes. Virol. J. 2016, 13, 1-14. [CrossRef] [PubMed]

60. Engelhardt, T.; Sahlberg, M.; Cypionka, H.; Engelen, B. Biogeography of Rhizobium radiobacter and distribution of associated temperate phages in deep subseafloor sediments. ISME J. 2012, 7, 199-209. [CrossRef]

61. Koonin, E.V.; Dolja, V.V.; Krupovic, M. Origins and evolution of viruses of eukaryotes: The ultimate modularity. Virology 2015, 479, 2-25. [CrossRef]

62. Weber, A.P.M.; Horst, R.J.; Barbier, G.G.; Oesterhelt, C. Metabolism and metabolomics of eukaryotes living under extreme conditions. Int. Rev. Cytol. 2007, 256, 1-34. [CrossRef]

63. Hurt, A.C.; Vijaykrishna, D.; Butler, J.; Baas, C.; Maurer-Stroh, S.; Silva-De-La-Fuente, M.C.; Medina-Vogel, G.; Olsen, B.; Kelso, A.; Barr, I.G.; et al. Detection of evolutionarily distinct avian influenza a viruses in Antarctica. mBio 2014, 5, e01098-14. [CrossRef]

64. Kibenge, M.J.T.; Iwamoto, T.; Wang, Y.; Morton, A.; Godoy, M.; Kibenge, F.S.B. Whole-genome analysis of piscine reovirus (PRV) shows PRV represents a new genus in family Reoviridae and its genome segment $\mathrm{S} 1$ sequences group it into two separate sub-genotypes. Virol. J. 2013, 10, 230. [CrossRef]

65. Ballinger, M.J.; Bruenn, J.A.; Hay, J.; Czechowski, D.; Taylor, D.J. Discovery and evolution of Bunyavirids in arctic phantom midges and ancient Bunyavirid-like sequences in insect genomes. J. Virol. 2014, 88, 8783-8794. [CrossRef]

66. Rosario, K.; Schenck, R.O.; Harbeitner, R.C.; Lawler, S.N.; Breitbart, M. Novel circular single-stranded DNA viruses identified in marine invertebrates reveal high sequence diversity and consistent predicted intrinsic disorder patterns within putative structural proteins. Front. Microbiol. 2015, 6, 696. [CrossRef] [PubMed]

67. Yoshida, M.; Takaki, Y.; Eitoku, M.; Nunoura, T.; Takai, K. Metagenomic analysis of viral communities in (Hado)Pelagic sediments. PLoS ONE 2013, 8, e57271. [CrossRef] [PubMed] 
68. Roth, S.J.; Tischer, B.K.; Kovacs, K.M.; Lydersen, C.; Osterrieder, N.; Tryland, M. Phocine herpesvirus 1 (PhHV-1) in harbor seals from Svalbard, Norway. Vet. Microbiol. 2013, 164, 286-292. [CrossRef] [PubMed]

69. Maat, D.S.; van Bleijswijk, J.D.L.; Witte, H.J.; Brussaard, C.P.D. Virus production in phosphorus-limited Micromonas pusilla stimulated by a supply of naturally low concentrations of different phosphorus sources, far into the lytic cycle. FEMS Microbiol. Ecol. 2016, 92, fiw136. [CrossRef]

70. Ziv, C.; Malitsky, S.; Othman, A.; Ben-Dor, S.; Wei, Y.; Zheng, S.; Aharoni, A.; Hornemann, T.; Vardi, A. Viral serine palmitoyltransferase induces metabolic switch in sphingolipid biosynthesis and is required for infection of a marine alga. Proc. Natl. Acad. Sci. USA 2016, 113, E1907-E1916. [CrossRef]

71. Zhang, W.; Zhou, J.; Liu, T.; Yu, Y.; Pan, Y.; Yan, S.; Wang, Y. Four novel algal virus genomes discovered from Yellowstone Lake metagenomes. Sci. Rep. 2015, 5, 15131. [CrossRef]

72. Varin, T.; Lovejoy, C.; Jungblut, A.D.; Vincent, W.F.; Corbeil, J. Metagenomic profiling of Arctic microbial mat communities as nutrient scavenging and recycling systems. Limnol. Oceanogr. 2010, 55, 1901-1911. [CrossRef]

73. Maat, D.S.; Crawfurd, K.J.; Timmermans, K.R.; Brussaard, C.P.D. Elevated CO2and phosphate limitation favor micromonas pusilla through stimulated growth and reduced viral impact. Appl. Environ. Microbiol. 2014, 80, 3119-3127. [CrossRef]

74. Slagter, H.A.; Gerringa, L.J.A.; Brussaard, C.P.D. Phytoplankton virus production negatively affected by iron limitation. Front. Mar. Sci. 2016, 3, 156. [CrossRef]

75. Pagarete, A.; Lanzén, A.; Puntervoll, P.; Sandaa, R.; Larsen, A.; Larsen, J.; Allen, M.J.; Bratbak, G. Genomic sequence and analysis of EhV-99B1, a new Coccolithovirus from the Norwegian fjords. Intervirology 2013, 56, 60-66. [CrossRef]

76. Villarreal, L.P.; Witzany, G. Viruses are essential agents within the roots and stem of the tree of life. J. Theor. Biol. 2010, 262, 698-710. [CrossRef] [PubMed]

77. Pagarete, A.; Kusonmano, K.; Petersen, K.; Kimmance, S.A.; Martínez, J.M.; Wilson, W.H.; Hehemann, J.-H.; Allen, M.J.; Sandaa, R.-A. Dip in the gene pool: Metagenomic survey of natural coccolithovirus communities. Virology 2014, 466, 129-137. [CrossRef] [PubMed]

78. Nissimov, J.I.; Pagarete, A.; Ma, F.; Cody, S.; Dunigan, D.D.; Kimmance, S.; Allen, M.J. Coccolithoviruses: A review of crosskingdom genomic thievery and metabolic thuggery. Viruses 2017, 9, 52. [CrossRef] [PubMed]

79. Morsy, M.; Oswald, J.; He, J.; Tang, Y.; Roossinck, M.J. Teasing apart a three-way symbiosis: Transcriptome analyses of Curvularia protuberata in response to viral infection and heat stress. Biochem. Biophys. Res. Commun. 2010, 401, 225-230. [CrossRef]

80. Márquez, L.M.; Redman, R.S.; Rodriguez, R.J.; Roossinck, M.J. A virus in a fungus in a plant: Three-way symbiosis required for thermal tolerance. Science 2007, 315, 513-515. [CrossRef]

81. Ng, T.F.F.; Chen, L.-F.; Zhou, Y.; Shapiro, B.; Stiller, M.; Heintzman, P.D.; Varsani, A.; Kondov, N.O.; Wong, W.; Deng, X.; et al. Preservation of viral genomes in 700-y-old caribou feces from a subarctic ice patch. Proc. Natl. Acad. Sci. USA 2014, 111, 16842-16847. [CrossRef]

82. Maat, D.S.; Biggs, T.; Evans, C.; Van Bleijswijk, J.D.L.; Van Der Wel, N.N.; Dutilh, B.E.; Brussaard, C. (Corina) Characterization and temperature dependence of arctic micromonas polaris viruses. Viruses 2017, 9, 134. [CrossRef]

83. Martínez, J.M.; Martin, S.J.; Wilson, W.H. Dynamics and genotypic composition of Emiliania huxleyi and their co-occurring viruses during a coccolithophore bloom in the North Sea. FEMS Microbiol. Ecol. 2012, 81, 315-323. [CrossRef]

84. Kimmance, S.A.; Allen, M.J.; Pagarete, A.; Martinez, J.M.; Wilson, W.H. Reduction in photosystem II efficiency during a virus-controlled Emiliania huxleyi bloom. Mar. Ecol. Prog. Ser. 2014, 495, 65-76. [CrossRef]

85. Fischer, M.G.; Allen, M.J.; Wilson, W.H.; Suttle, C.A. Giant virus with a remarkable complement of genes infects marine zooplankton. Proc. Natl. Acad. Sci. USA 2010, 107, 19508-19513. [CrossRef]

86. Gallot-Lavallée, L.; Blanc, G. A Glimpse of nucleo-cytoplasmic large DNA virus biodiversity through the eukaryotic genomics window. Viruses 2017, 9, 17. [CrossRef] [PubMed]

87. Zhou, J.; Sun, D.; Childers, A.; McDermott, T.R.; Wang, Y.; Liles, M.R. Three novel virophage genomes discovered from Yellowstone Lake Metagenomes. J. Virol. 2015, 89, 1278-1285. [CrossRef]

88. Yau, S.; Lauro, F.M.; DeMaere, M.Z.; Brown, M.V.; Thomas, T.; Raftery, M.J.; Andrews-Pfannkoch, C.; Lewis, M.; Hoffman, J.M.; Gibson, J.A.; et al. Virophage control of antarctic algal host-virus dynamics. Proc. Natl. Acad. Sci. USA 2011, 108, 6163-6168. [CrossRef] [PubMed]

89. Prasch, C.M.; Sonnewald, U. Simultaneous application of heat, drought, and virus to arabidopsis plants reveals significant shifts in signaling networks. Plant Physiol. 2013, 162, 1849-1866. [CrossRef] [PubMed]

90. Van Munster, M.; Yvon, M.; Vile, D.; Dader, B.; Fereres, A.; Blanc, S. Water deficit enhances the transmission of plant viruses by insect vectors. PLoS ONE 2017, 12, e0174398. [CrossRef] [PubMed]

91. Brister, J.R.; Ako-Adjei, D.; Bao, Y.; Blinkova, O. NCBI viral genomes resource. Nucleic Acids Res. 2015, 43, D571-D577. [CrossRef]

92. NCBI. NCBI: Viral Genomes. 2020. Available online: https://www.ncbi.nlm.nih.gov/genomes/GenomesGroup.cgi?taxid=10239 (accessed on 7 July 2020).

93. Coker, J.A. Extremophiles and biotechnology: Current uses and prospects. F1000Research 2016, 5, 396. [CrossRef]

94. Xiao-Ran, J.; Jin, Y.; Xiangbin, C.; Chen, G.-Q. Halomonas and pathway engineering for bioplastics production. In Methods in Enzymology; Elsevier BV: Amsterdam, The Netherlands, 2018; Volume 608, pp. 309-328.

95. Scheid, P.L. A strange endocytobiont revealed as largest virus. Curr. Opin. Microbiol. 2016, 31, 58-62. [CrossRef] 
96. Liu, Y.; Wang, J.; Liu, Y.; Wang, Y.; Zhang, Z.; Oksanen, H.M.; Bamford, D.H.; Chen, X. Identification and characterization of $\mathrm{SNJ} 2$, the first temperate pleolipovirus integrating into the genome of the SNJ1-lysogenic archaeal strain. Mol. Microbiol. 2015, 98, 1002-1020. [CrossRef]

97. Growth, A.C.; Calos, M.P. Phage integrases: Biology and applications. J. Mol. Biol. 2004, 335, 667-678. [CrossRef]

98. Fogg, P.C.; Colloms, S.; Rosser, S.; Stark, M.; Smith, M.C.M. New applications for phage integrases. J. Mol. Biol. 2014, 426, 2703-2716. [CrossRef] [PubMed]

99. Merrick, C.A.; Zhao, J.; Rosser, S.J. Serine integrases: Advancing synthetic biology. ACS Synth. Biol. 2018, 7, 299-310. [CrossRef]

100. Moser, M.J.; DiFrancesco, R.A.; Gowda, K.; Klingele, A.J.; Sugar, D.R.; Stocki, S.; Mead, D.A.; Schoenfeld, T. Thermostable DNA Polymerase from a viral metagenome is a potent RT-PCR enzyme. PLoS ONE 2012, 7, e38371. [CrossRef] [PubMed]

101. Chander, Y.; Koelbl, J.; Puckett, J.; Moser, M.J.; Klingele, A.J.; Liles, M.R.; Carrias, A.; Mead, D.A.; Schoenfeld, T. A novel thermostable polymerase for RNA and DNA loop-mediated isothermal amplification (LAMP). Front. Microbiol. $2014,5,395$. [CrossRef] [PubMed]

102. Heller, R.C.; Chung, S.; Crissy, K.; Dumas, K.; Schuster, D.; Schoenfeld, T.W. Engineering of a thermostable viral polymerase using metagenome-derived diversity for highly sensitive and specific RT-PCR. Nucleic Acids Res. 2019, 47, 3619-3630. [CrossRef] [PubMed]

103. Goulet, A.; Pina, M.; Redder, P.; Prangishvili, D.; Vera, L.; Lichière, J.; Leulliot, N.; van Tilbeurgh, H.; Ortiz-Lombardia, M.; Campanacci, V.; et al. ORF157 from the archaeal virus Acidianus filamentous virus 1 defines a new class of nuclease. J. Virol. 2010, 84, 5025-5031. [CrossRef] [PubMed]

104. Schoenfeld, T.W.; Murugapiran, S.K.; Dodsworth, J.A.; Floyd, S.; Lodes, M.; Mead, D.A.; Hedlund, B.P. Lateral gene transfer of family A DNA polymerases between thermophilic viruses, aquificae, and apicomplexa. Mol. Biol. Evol. 2013, 30, $1653-1664$. [CrossRef]

105. Uldahl, K.B.; Wu, L.; Hall, A.; Papathanasiou, P.; Peng, X.; Moghimi, S.M. Recognition of extremophilic archaeal viruses by eukaryotic cells: A promising nanoplatform from the third domain of life. Sci. Rep. 2016, 6, 37966. [CrossRef] [PubMed]

106. Wu, L.-P.; Uldahl, K.B.; Chen, F.; Benasutti, H.; Logvinski, D.; Vu, V.; Banda, N.K.; Peng, X.; Simberg, D.; Moghimi, S.M. Interaction of extremophilic archaeal viruses with human and mouse complement system and viral biodistribution in mice. Mol. Immunol. 2017, 90, 273-279. [CrossRef]

107. Röder, J.; Dickmeis, C.; Commandeur, U. Small, smaller, nano: New applications for potato virus X in nanotechnology. Front. Plant. Sci. 2019, 10, 158. [CrossRef]

108. Schoenfeld, T.; Patterson, M.; Richardson, P.M.; Wommack, K.E.; Young, M.; Mead, D. Assembly of Viral Metagenomes from Yellowstone Hot Springs. Appl. Environ. Microbiol. 2008, 74, 4164-4174. [CrossRef] [PubMed]

109. Wang, F.; Ji, X.; Li, Q.; Zhang, G.; Peng, J.; Hai, J.; Zhang, Y.; Ci, B.; Li, H.; Xiong, Y.; et al. TSPphg Lysin from the Extremophilic Thermus Bacteriophage TSP4 as a Potential Antimicrobial Agent against Both Gram-Negative and Gram-Positive Pathogenic Bacteria. Viruses 2020, 12, 192. [CrossRef] [PubMed]

110. Magdalena, P.; Enea, S.-V.; Sebastian, D.; Anna-Karina, K.; Kozlowski, L.P.; Kaczorowski, T.; Zeth, O. Structure and function of the Ts2631 endolysin of Thermus scotoductus phage vB_Tsc2631 with unique N-terminal extension used for peptidoglycan binding. Sci. Rep. 2019, 9. [CrossRef]

111. Zimmerman, A.E.; Howard-Varona, C.; Needham, D.M.; John, S.G.; Worden, A.Z.; Sullivan, M.B.; Waldbauer, J.R.; Coleman, M.L. Metabolic and biogeochemical consequences of viral infection in aquatic ecosystems. Nat. Rev. Microbiol. 2020, 18, 21-34. [CrossRef] [PubMed]

112. Fernandes, S.; São-José, C. Enzymes and mechanisms employed by tailed bacteriophages to breach the bacterial cell barriers. Viruses 2018, 10, 396. [CrossRef] [PubMed]

113. Littlechild, J. Enzymes from extreme environments and their industrial applications. Front. Bioeng. Biotechnol. 2015, 3, 1-9. [CrossRef]

114. Sewankambo, N.; Tumwine, J.K.; Tomson, G.; Obua, C.; Bwanga, F.; Waiswa, P.; Katabira, E.; Akuffo, H.; Persson, K.E.M.; Peterson, S. Enabling dynamic partnerships through joint degrees between low-and high-income countries for capacity development in global health research: Experience from the Karolinska Institutet/Makerere University Partnership. PLoS Med. 2015, 12, e1001784. [CrossRef]

115. Flint, S.; Bremer, P.; Brooks, J.; Palmer, J.; Sadiq, F.A.; Seale, B.; Teh, K.H.; Wu, S.; Zain, S.N.M. Bacterial fouling in dairy processing. Int. Dairy J. 2020, 101, 104593. [CrossRef]

116. Roohi; Bano, K.; Kuddus, M.; Zaheer, M.R.; Zia, Q.; Khan, M.F.; Ashraf, G.M.; Gupta, A.; Aliev, G. Microbial enzymatic degradation of biodegradable plastics. Curr. Pharm. Biotechnol. 2017, 18, 429-440. [CrossRef]

117. Reath, K.; Pritchard, M.; Moruzzi, S.; Alcott, A.; Coppola, D.; Pieri, D. The AVTOD (ASTER Volcanic Thermal Output Database) Latin America archive. J. Volcanol. Geotherm. Res. 2019, 376, 62-74. [CrossRef]

118. Liebig, T.; Jassogne, L.; Rahn, E.; Läderach, P.; Poehling, H.-M.; Kucel, P.; Van Asten, P.; Avelino, J. Towards a collaborative research: A case study on linking science to farmers' perceptions and knowledge on Arabica coffee pests and diseases and its management. PLoS ONE 2016, 11, e0159392. [CrossRef] [PubMed] 